\title{
Performance of steel structures during the 1994 Northridge earthquake
}

\author{
Robert Tremblay, Peter Timler, Michel Bruneau, and \\ André Filiatrault
}

\begin{abstract}
The performance of concentrically braced steel frames and moment resisting steel frames during the January 17, 1994, Northridge, California, earthquake is examined. Most of the observations made during the reconnaissance visits confirmed the current knowledge on the inelastic response of these structural systems. This permits the anticipation of proper seismic behavior for buildings designed according to the seismic provisions that have been recently introduced in the Canadian building code and standard for steel structures. In some cases, however, the observed damage raised concerns that should be addressed in future investigations or next editions of these codes. Preventing potentially hazardous nonstructural damage, avoiding premature nonductile failures anywhere along the lateral load paths, limiting structural and nonstructural damage due to brace buckling, and accounting for the vertical ground motion are among those issues.
\end{abstract}

Key words: earthquake, seismic, steel, concentrically braced frames, moment resisting frames, weld.

Résumé : Dans cet article, on examine et commente le comportement de charpentes métalliques avec contreventement en treillis ou cadres rigides lors du séisme qui a eu lieu le 17 janvier 1994 à Northridge, en Californie. La majorité des observations faites lors des visites effectuées sur le site confirment les connaissances déjà acquises sur le comportement non linéaire de ces systèmes structuraux lorsque soumis aux séismes. Ceci permet de croire que les bâtiments conçus selon les dispositions séismiques nouvellement introduites dans le code du bâtiment canadien et la norme canadienne pour la calcul des structures d'acier seront adéquats dans l'éventualité de tremblements de terre importants. Dans certains cas, cependant, les dommages subis soulèvent des interrogations qui devraient faire l'objet d'études futures en vue d'améliorer ces normes. Parmi les points qui devraient être examinés, on retrouve la prévention des dommages non-structuraux à risque, la prévention de ruptures subites et non-ductiles le long du cheminement des efforts induits par les charges latérales, la réduction des dommages imposées aux éléments structuraux ou non-structuraux lors du flambement des membrures diagonales des contreventements ainsi que la prise en compte des effets des mouvements verticaux du sol.

Mots clés : tremblement de terre, séisme, charpentes métalliques, contreventement en treillis, cadre rigide, soudure.

\section{Introduction}

The earthquake resistance of steel frames has been known to be tremendously reliable overall, with steel building collapses so far being the rare occurrence worldwide (Yanev et al. 1991). In the January, 1994, Northridge earthquake, steel frames also sustained well the ground shaking, as no fatali-

Received June 16, 1994.

Revised manuscript accepted December 22, 1994.

R. Tremblay and A. Filiatrault. Department of Civil Engineering, École polytechnique, Montreal, QC H3C 3A7, Canada.

P. Timler. Sandwell Inc., Engineering and Construction Services Group, 1190 Hornby Street, Vancouver, BC V6Z 2H6, Canada.

M. Bruneau. Ottawa-Carleton Earthquake Engineering Research Center, Department of Civil Engineering, University of Ottawa, Ottawa, ON K1N 6N5, Canada.

Written discussion of this paper is welcomed and will be received by the Editor until August 31, 1995 (address inside front cover). ties were attributed to unsatisfactory performance of steel structures and no collapses of steel buildings were reported (AISC 1994a).

However, evidences of significant inelastic response and several structural deficiencies were observed on steel-framed structures after the event. Most of these observations corroborate the current state-of-the-art in seismic design in Canada. Nevertheless, some cases need to be brought to the attention of the Canadian engineering community. The reflection on these cases may lead to modifications to our present design and construction practices in order to ensure that safer steel structures be built in the future.

This paper reports and comments on the observations made by reconnaissance team members of the Canadian Association for Earthquake Engineering (CAEE), which visited the epicentral area of the Northridge earthquake. Contributions from local structural engineers were also included in the paper for sake of completeness. A total of 14 cases are presented, among which 12 are building structures. The structures were either concentrically braced frames, moment resisting frames, or a combination of the two. 
The first part of the paper outlines the characteristics and reviews the relevant seismic design fundamentals of steel concentrically braced frames and moment resisting frames. The observations from the reconnaissance site visits are presented in the second part of the paper. Finally, for each structural system, a comparison between the observed behavior and the performance expected by the design provisions included in the current edition of the National Building Code of Canada (NBCC) (NRCC 1990) and standard for steel structures (CSA 1989) is presented.

\section{Seismic design fundamentals of steel concentrically braced and moment resisting frames}

\section{Concentrically braced frames}

For low- and medium-rise structures, the concentrically braced frame system has been extremely popular. It is simple to design and fabricate and allows the required lateral strength and stiffness to be easily provided at a low cost.

Lateral stability of concentrically braced frames is ensured by vertical cantilevered trusses anchored to the foundation. This truss action is achieved by introducing diagonal bracing members within the main beam and column framework. For ease of design and construction, simple beam-column connections are most often used throughout the structure. With this system, lateral loads primarily induce axial loads in the members of the bracing bents. Therefore, inelastic action under the design base earthquake is associated with axial deformations in these members.

To maintain the gravity load carrying capacity of beams and columns during the ground shaking, axial inelastic deformations in these members are not desirable. On the other hand, bracing members carry little or no gravity loads. Thus, these diagonal members are good candidates to act as critical elements in concentrically braced frames to form the energy absorbing and dissipating mechanism of the lateral load resisting system.

Braces can dissipate energy through yielding in tension and, additionally, through inelastic buckling in compression. Numerous investigations (e.g., Popov and Black 1981) have shown that the latter is achieved by using stockier braces. Upon buckling, a plastic hinge forms at mid-length of the brace and, possibly, at its ends depending on the fixity conditions. Energy is absorbed through inelastic bending of the plastic hinges under compressive loads as well as upon straightening up of the brace during subsequent tension loading. Width-to-thickness ratios of the bracing members must be kept low to prevent local buckling and premature failure at the hinge locations.

Ductile and stable behavior of concentrically braced frames can be expected under severe ground shaking if inelastic response is constrained to properly detailed bracing members, and if brittle failure is avoided in the other components of the lateral load resisting system. Comprehensive seismic design provisions have been introduced recently in the Canadian S16.1 standard (CSA 1989) to meet these capacity design objectives (Redwood and Channagiri 1991). The extent of detailing prescribed for concentrically braced frames depends on the magnitude of the anticipated inelastic deformations, and is therefore related to the seismic load level adopted in design. This is done by defining three different categories of bracing systems for which a different design seismic load level is prescribed by the NBCC. For each category, a different set of seismic detailing provisions is required by the S16.1 standard.

The first category is referred to as ductile braced frames for which a ductile behavior is mandatory for its survival during the design base earthquake. The storey shear must be shared between tension- and compression-acting braces. The slenderness ratio of the bracing members is limited and a maximum width-to-thickness ratio is prescribed for the flat elements of their cross section. Capacity design provisions are also included to avoid overstressing, upon brace yielding, of the brace connections and of the columns and beams within the bracing bents.

The second bracing system category considered by the code requires only nominal ductility and, therefore, is assigned design seismic loads $50 \%$ higher than the ones for the previous category. Braced frames of the third category, referred to herein as ordinary braced frames, rely only on the inherent ductility of the steel material for resistance to earthquakes. No ductile detailing requirements, nor any capacity design provisions, are specified for these frames. However, they have to be designed for twice the loads prescribed for ductile braced frames.

Chevron bracing is the concentrically braced frame configuration most often observed by the authors in the Northridge area. In this bracing scheme, two bracing members form an inverted $\mathrm{V}$ shape at each storey, with the apex being located at mid-span of the upper floor beam. This widely used configuration exhibits high efficiency in the elastic range (White and Salmon 1987) and allows more flexibility for creating openings in the bracing bents. Once buckling of both braces has occurred, however, the storey shear resistance and stiffness typically degrade rather rapidly (Khatib et al. 1988). Therefore, during severe ground shaking, chevron braced frames are likely to experience larger deformations. For multistorey structures, they are also more susceptible to concentration of large storey drifts within a single storey (soft-storey mechanism) than other configurations. In Canada, this system cannot classify under the ductile braced frame category and must be designed for higher seismic loads.

\section{Moment resisting frames}

For low- and medium-rise structures, moment resisting frames are generally less economical than braced frames for sustaining horizontal loads in the elastic range. They are more flexible and stiffness often governs the choice of the members. In seismically active regions such as California, however, moment resisting frames represent the essential lateral load resisting system for multistorey structures. This system exhibits high redundancy and high energy absorbing and dissipating capabilities which overcome its less attractive characteristics in the elastic range. Also, since no bracing members are present, openings can be cut anywhere in the structure.

In moment resisting frames, the beams are rigidly connected to the columns and lateral loads are resisted through bending of these elements. Many types of beam-to-column joints have been developed over the years, among which the welded flange and bolted web type has become very popular 
Table 1. Summary of observed structural damage.

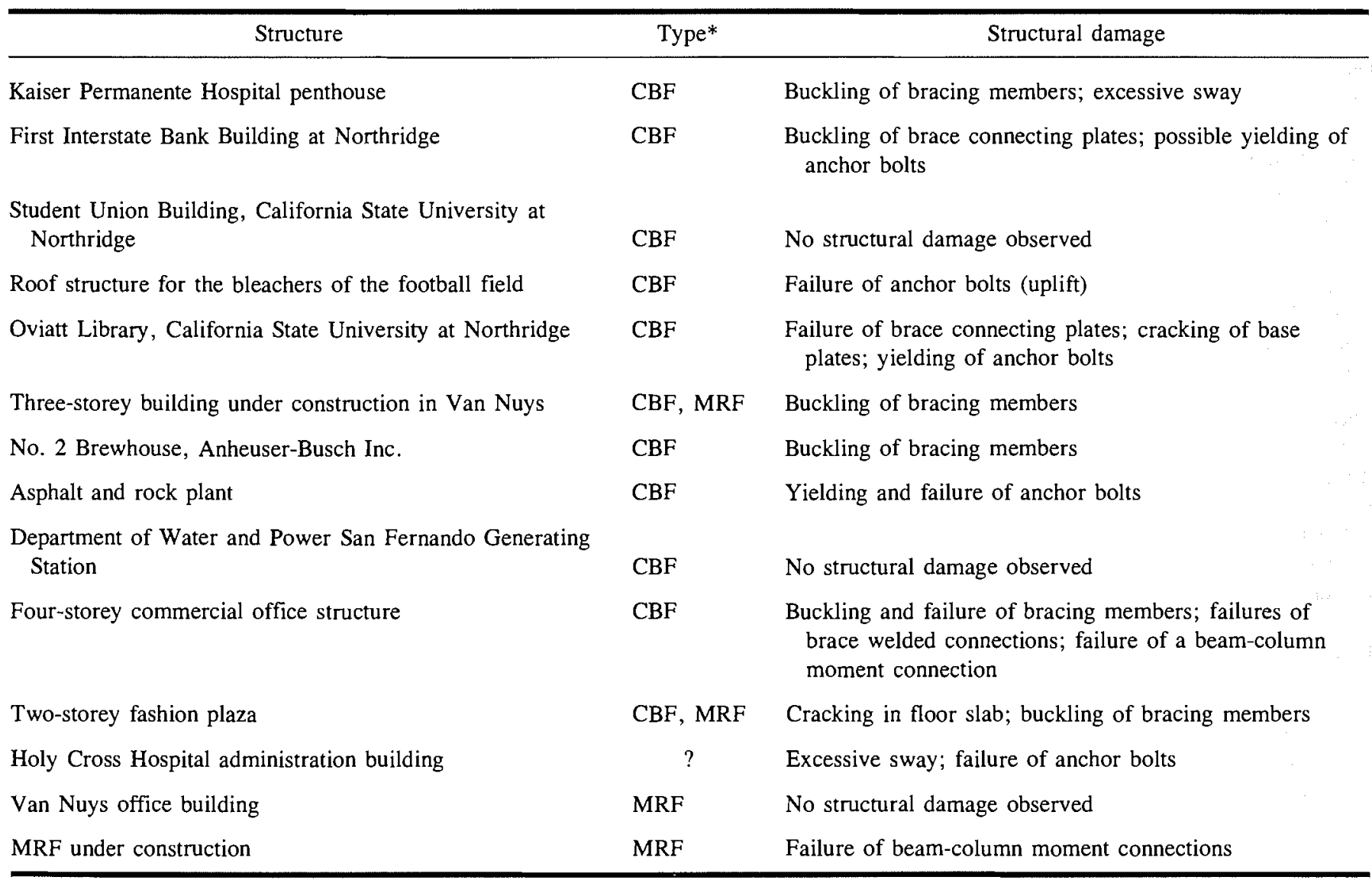

*CBF: concentrically braced frame; MRF: moment resisting frame.

for earthquake resistance. This connection includes a bolted web connection for carrying vertical shear whereas bending moments are transmitted by complete penetration welding of the beam flanges to the column (Fig. 43). For proper welding, weld backing or backing bars are used underneath the beam flanges to support and retain the molten weld metal.

During ground shaking, energy can be dissipated through any one, or any combination, of the following mechanisms: plastic hinging in the beams, shear yielding in the panel zone of the beam-to-column connections, or plastic hinging in the columns. The latter is less desirable as it can lead more easily to the formation of a single-storey collapse mechanism, and because it is expected to result in larger storey drifts (Roeder et al. 1989). Since allowing inelastic action in the panel zone has been recognized only recently, most moment resisting frames built in California have been designed according to the weak beam strong column philosophy with flexural yielding limited to the beams. For such a mechanism, current U.S. codes (AISC 1992; ICBO 1994) consider the welded flange and bolted web beam-column joint adequate to develop the flexural strength of the beam without tests or calculations, provided that the joint conforms to simple rules.

Similarly, in Canada, comprehensive seismic design provisions have also been introduced for moment resisting frames in the S16.1 standard (Redwood et al. 1990). For the most ductile system, stringent requirements for sizing the critical elements are prescribed to ensure a proper ductile behavior of the three possible mechanisms (beam or column hinging and panel zone shear yielding). Capacity design rules are also specified in order to avoid brittle failures in the remaining components. In particular, when beam hinging is a critical element, welding of the beam flanges to the column must develop the actual flexural strength of the beam.

\section{Diaphragms and anchorage to foundations}

For both concentrically braced frames and moment resisting frames, the lateral load resisting system of the buildings visited in Northridge also included floor and roof diaphragms to collect and transfer horizontal loads to the vertical bracing elements. Although it is implicitly assumed in design that no brittle failure is to occur in the diaphragms, no explicit capacity design provisions are included in current design standards for these elements and their connections. These provisions are also absent for the anchorage systems at the base of the vertical bracing elements.

\section{Observations after the Northridge earthquake}

A few days after the main shock of the Northridge earthquake, the authors visited the affected area for a period of about a week. The third author returned for a second investigation three months after the event. During that time, the authors stayed in contact with local engineers and authorities to follow up on the latest developments in terms of new observations, demolitions, retrofits, and repairs. The various 
Fig. 1. Kaiser Permanente Hospital: cladding loss on penthouse.

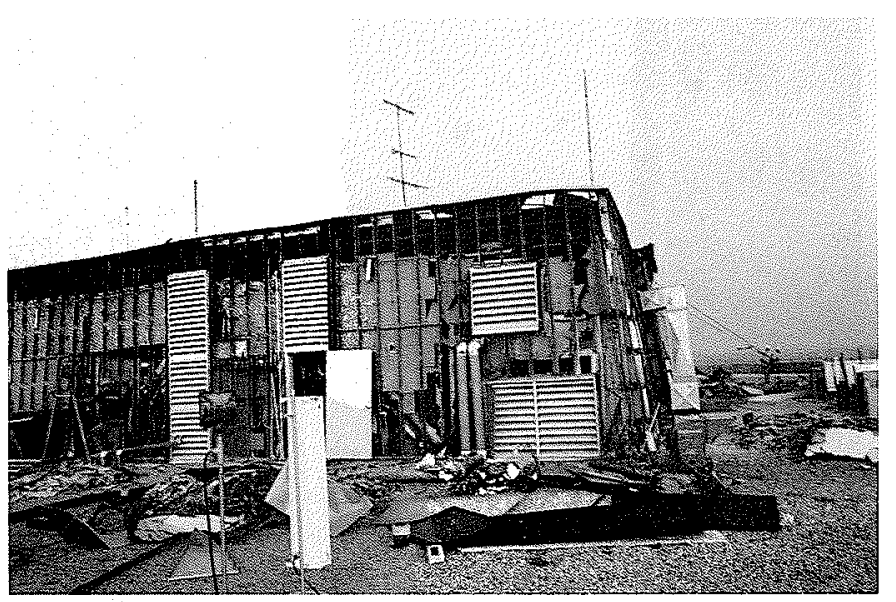

cases presented below represent up-to-date information at the time of writing (May 1994) on the structures visited by the authors. A summary of the observed structural damage is presented in Table 1.

\section{Kaiser Permanente Hospital penthouse, Panorama City} This existing hospital was a ten-storey reinforced concrete building located only a few kilometres from the Northridge epicenter. The facility suffered significant mechanical (HVAC) losses due to severe damage to a steel framed penthouse. This mechanical room was constructed from a light structural steel frame with a cast-in-place concrete roof deck incorporating double angle chevron bracing. The penthouse was severely racked in the north-south direction displaying near complete cladding loss and extreme buckling (both in-plane and out-of-plane) of the bracing system (Figs. 1 and 2).

Since the electrical, plumbing, and ventilation were rigidly connected to both the roof soffit and walls, their associated systems suffered either damage or service loss resulting in the closure of the top three floors of the hospital until repairs could resume their functionality (Fig. 3 ). It is estimated that the hospital's capacity for patient care was reduced to approximately the $60 \%$ level as a result of mechanical penthouse failures.

\section{First Interstate Bank Building at Northridge}

This is a two-storey steel frame, $25 \times 46 \mathrm{~m}$ in plan, located on Nordhoff Street in Northridge, approximately $2 \mathrm{~km}$ north of the epicenter. It was built in the mid-1970s and seismically retrofitted in 1991. In the north-south direction, the frame was concentrically braced along both end walls. As part of the retrofit effort, four X-bracing bays were added at both levels along the facade (two of them are shown in Fig. 4). The performance of these four bracing assemblies is examined herein.

The X-bracing members were made from short legs backto-back L102 × $76 \times 6.4(4 \times 3 \times 1 / 4$ in.) angles. At the intersection of the braces, one brace was interrupted and continuity was provided by a connecting plate. All connections were welded. The connecting plates showed evidence of severe buckling and bending, whereas no indication of inelastic action, nor buckling, could be observed along the
Fig. 2. Kaiser Permanente Hospital: buckled double angle chevron bracing in penthouse.

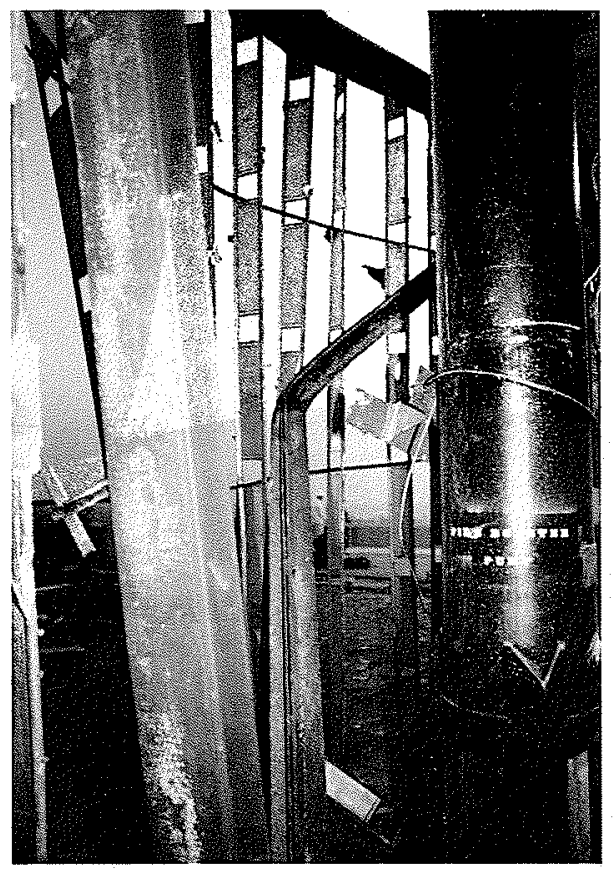

Fig. 3. Kaiser Permanente Hospital: racking of services attached to penthouse roof.

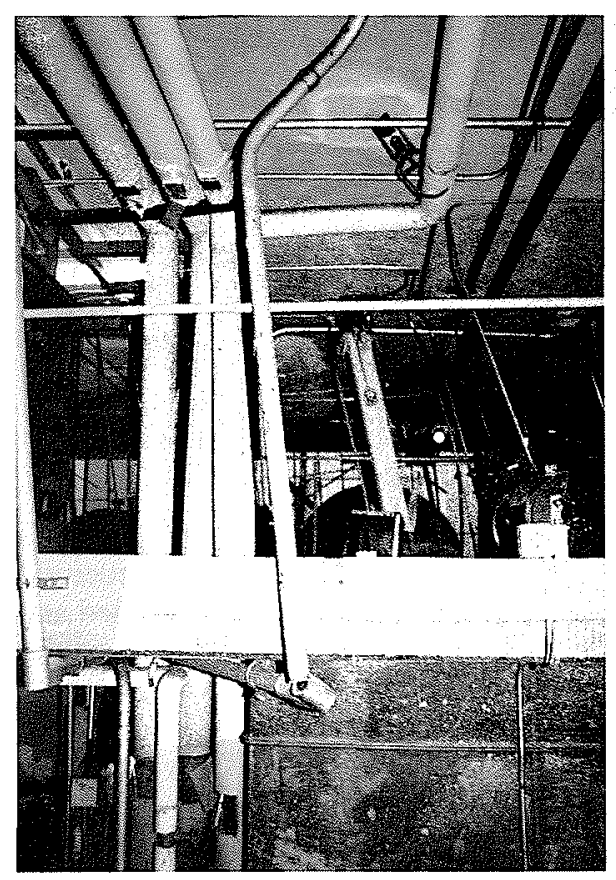

bracing members (Fig. 5). At the base of the columns of the $\mathrm{X}$-braced bays, evidence of uplift could be observed, as the tiles on the ground and the stucco covering the columns were damaged (Fig. 6). This suggests that neither the anchorage nor the brace connecting plates could sustain the load that developed in the braces.

Serious nonstructural damage, indicating that the structure had experienced significant deformations, could also be 
Fig. 4. First Interstate Bank Building in Northridge: steel $\mathrm{X}$-bracing in the facade.
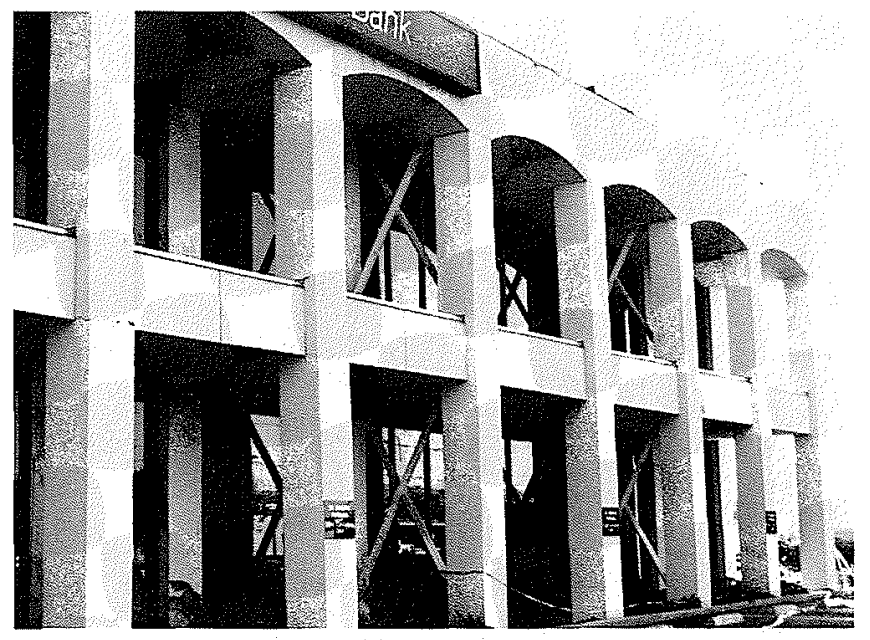

Fig. 5. First Interstate Bank Building in Northridge: buckling of connecting plate at brace intersection.

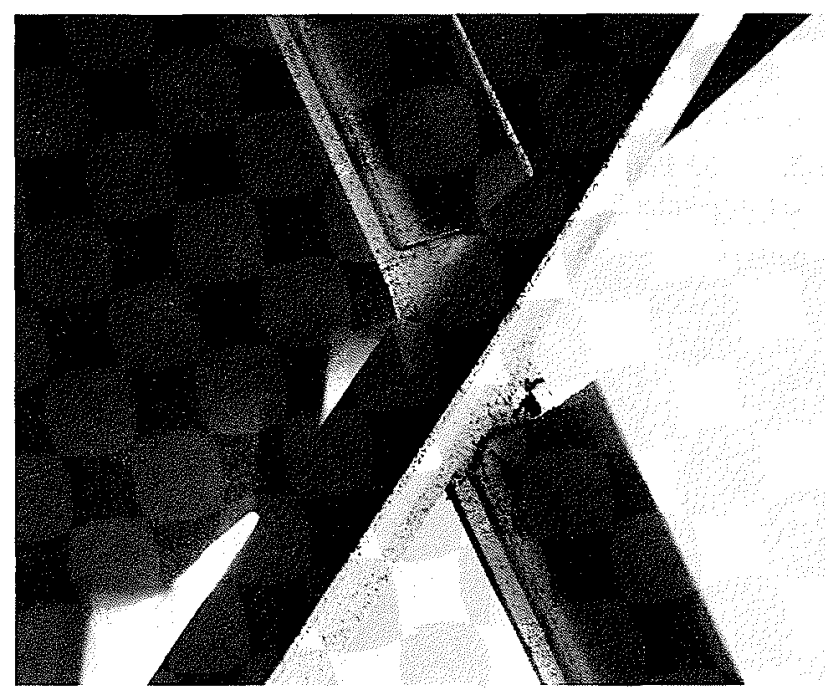

observed. According to recent discussions with the owner's representative, the extent of structural and nonstructural damage was such that the building has to be demolished and rebuilt. It is the owner's intention to replace it with a singlestorey timber construction.

\section{Student Union Building, California State University at Northridge}

Of course, not all the steel structures visited had suffered damage during the Northridge earthquake. For instance, on the Northridge campus of the California State University, which was located within $3 \mathrm{~km}$ from the epicenter of the main shock, a four-storey concentrically braced structure was under construction when hit by the earthquake (Fig. 7). The structure was well braced and well detailed in the connection and panel zone regions of beam and column interactions (Fig. 8). No structural damage was observed, although it is recognized that its intended full design dead loading was not in place during the earthquake.
Fig. 6. First Interstate Bank Building in Northridge: column uplift at the base of the X-bracing.

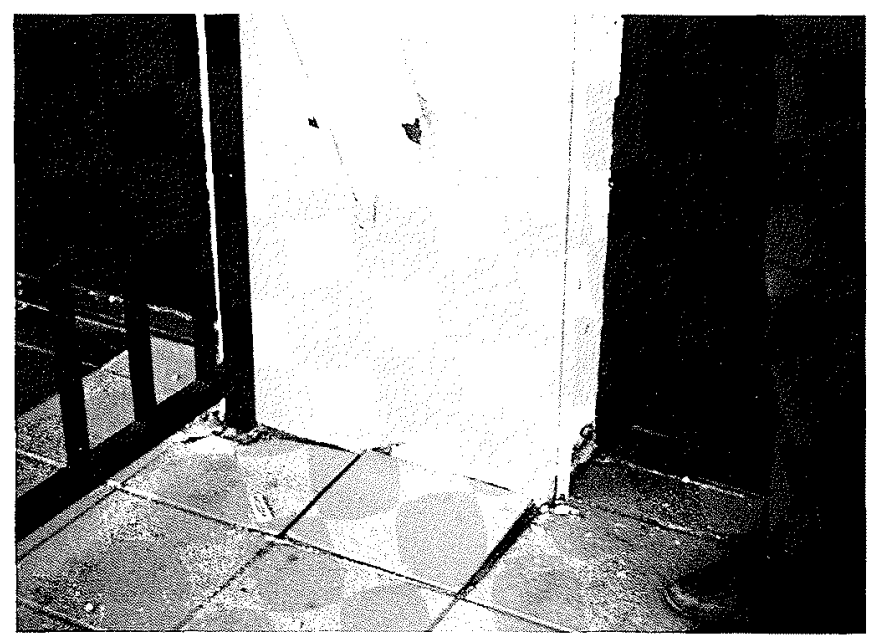

Fig. 7. Student Union Building at the California State University at Northridge: exterior view of building bracing system.

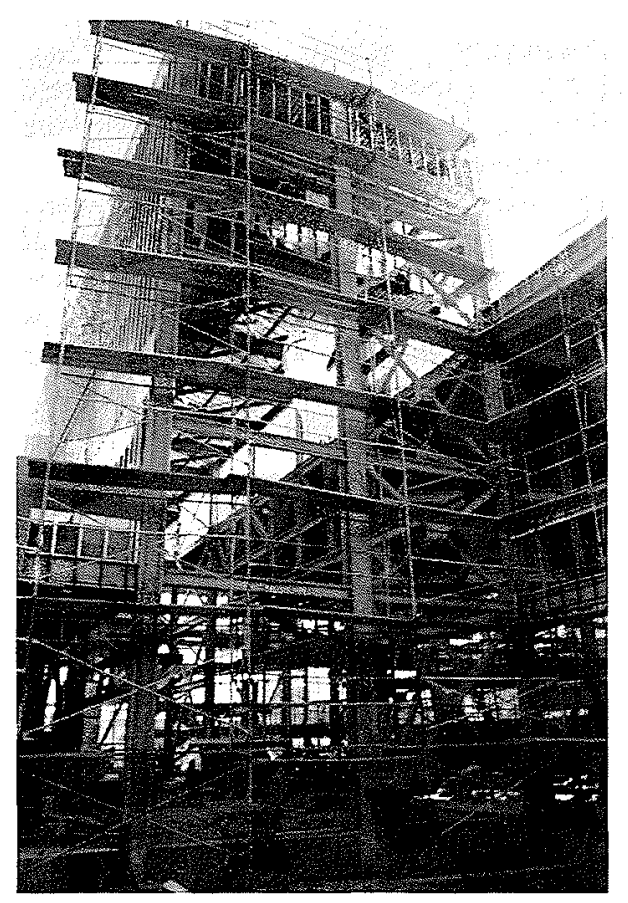

Roof structure for the bleachers of the football field, California State University at Northridge

West of Zelzah Avenue, near Fullerfarm Street, stands the football field of the California State University at Northridge, approximately $5 \mathrm{~km}$ north of the epicenter. A steel structure built around 1970 sheltered the bleachers located along the west side of the field. The roof structure included corrugated steel panels bearing on purlins spanning between 18 main cantilevered steel trusses, approximately $10 \mathrm{~m}$ long, that were spaced at $5.2 \mathrm{~m}$ on center along the length of the field. The clear height below the trusses was $3.6 \mathrm{~m}$.

Each cantilever truss was supported by a single W200 $\times 36$ (W8 $\times 24$ ) column located $7.4 \mathrm{~m}$ from the front edge of the 
Fig. 8. Student Union Building at the California State University at Northridge: interior view of building bracing and details.

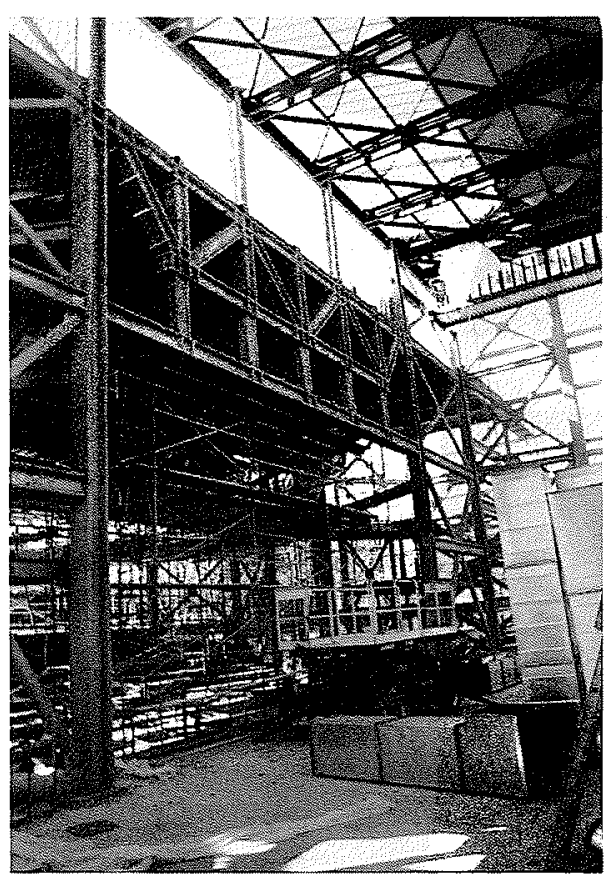

Fig. 9. Roof structure covering the bleachers of the football field at the California State University at Northridge: cantilevered steel frames.

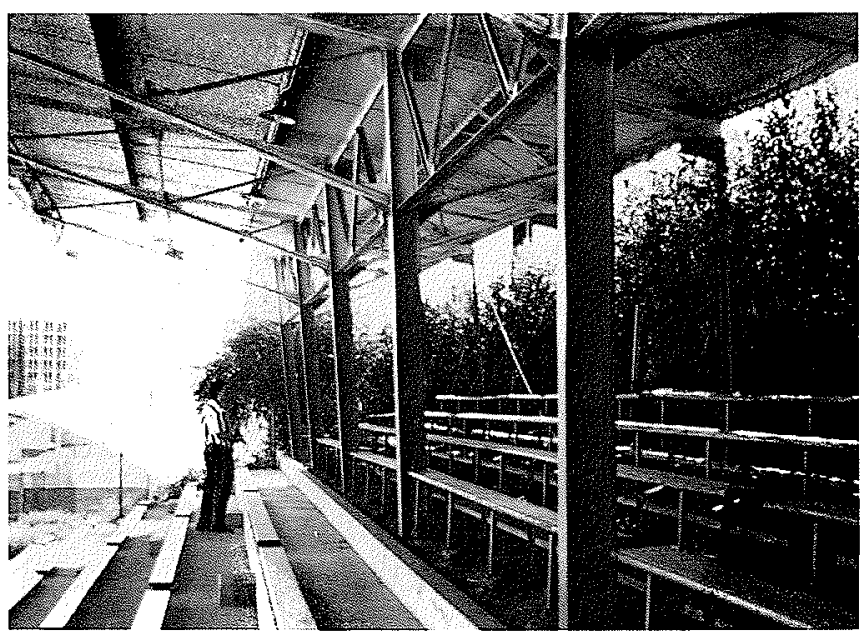

roof and was tied down to the foundations at the back by means of short legs back-to-back L63 $\times 63 \times 6.4 \mathrm{~mm}(21 / 2 \times$ $2 \frac{1}{2} \times 1 / 4$ in.) angle ties (Fig. 9). Anchorage of the ties to the foundation was achieved by a $6.4 \mathrm{~mm}$ thick base plate with two $19 \mathrm{~mm}$ anchor bolts spaced $90 \mathrm{~mm}$ on center. Bracing in the direction parallel to the field (north-south) was provided by three two-bay inverted $V$ tension-only systems made of $19 \mathrm{~mm}$ diagonal steel rods inserted between the vertical back ties of the roof trusses.

The first four bays at the south end of the roof structure exhibited approximately a $5^{\circ}$ inclination towards the bleachers (Fig. 9) as a result of the failure of the anchor bolts of the
Fig. 10. Roof structure covering the bleachers of the football field at the California State University at Northridge: uplift of the back ties.

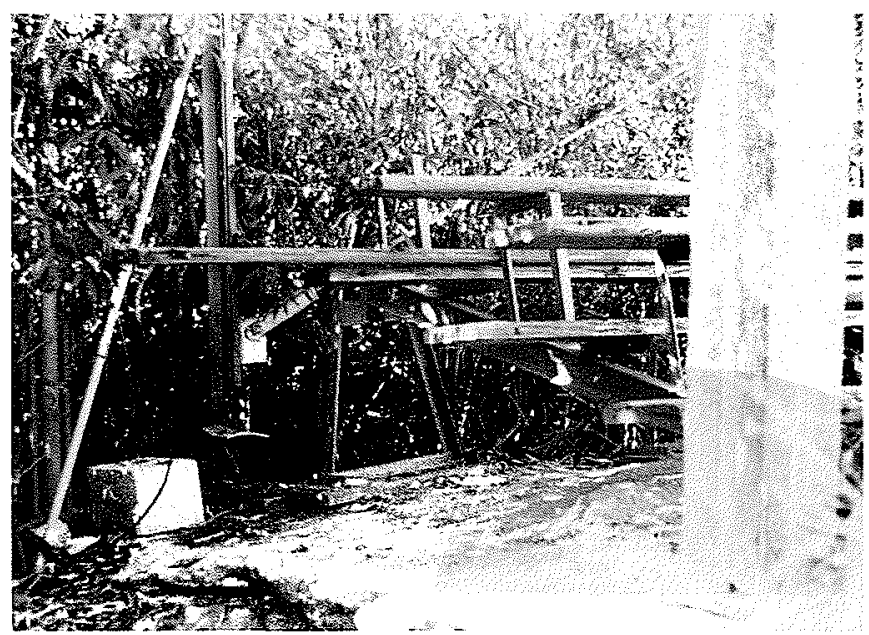

Fig. 11. Oviatt Library Building at the California State University at Northridge: failure of the overhanging roof.

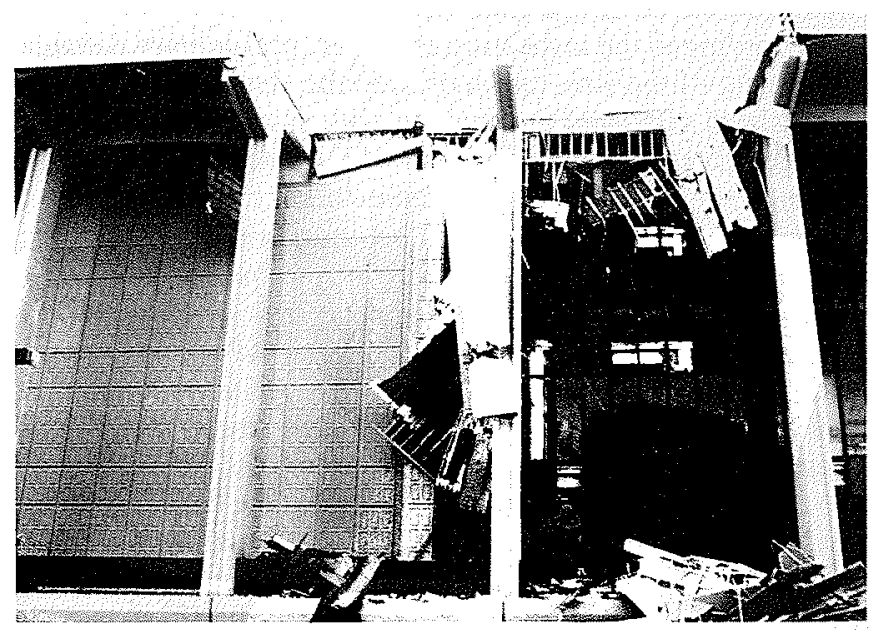

back ties during the earthquake (Fig. 10). Complete collapse of these four bays was inhibited only by the rotational restraint offered by the column base plate. The fact that anchor bolt failures occurred at the base of ties where longitudinal bracing diagonal members were attached as well as at the base of ties with no such diagonal members indicates that vertical accelerations undergone by the cantilevered roof likely contributed to the observed damage. According to the owner's representative, the structure has been dismantled after the earthquake and was to be replaced with a new one.

Oviatt Library, California State University at Northridge This is a four-storey building including a concrete framed central part built in 1971. Two wings made of steel braced frames were added in 1991 at the east and west ends. The building had a steel framed overhanging roof along its perimeter. At two locations along the north wall, the steel beams of that projected roof running parallel to the exterior wall, and spanning across an expansion joint in the main framework, collapsed (Fig. 11). This failure has been attrib- 
Fig. 12. Three-storey building under construction in Van Nuys: chevron bracing on the north wall.

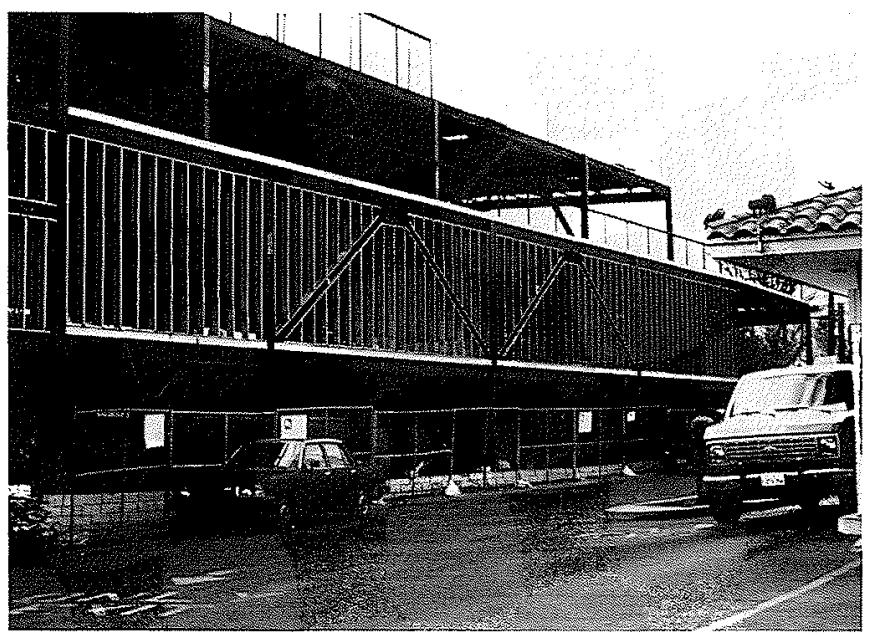

uted to the loss of bearing support of these beams and pounding damage due to the relative horizontal movement that took place at the expansion joints. No other structural damage could be noticed at the time of the visit.

According to the inspecting engineer, preliminary damage assessment of the structure indicated the steel braced frames had resisted very well the shaking with essentially no visible damage. Later on, upon removal of the interior finishing, a thorough inspection of the framework revealed a brittle failure of the welded connection between brace gusset plates and base plates as well as fracture of the base plates themselves at the bottom of approximately $75 \%$ of the columns located within the bracing bents. Many of the $63 \mathrm{~mm}$ anchor bolts used for these columns also suffered inelastic elongation up to $12 \mathrm{~mm}$. In one case, the bolt failed in tension. These failures have been reported elsewhere (EERI 1994). So far, the investigation demonstrated that the capacity of the welds was well below the actual strength of the bracing members and, thereby, below the forces that likely developed in these members during the shaking. It is believed that such failures "protected" the braced frames from undergoing inelastic action during the shaking but, on the other hand, likely resulted in larger horizontal deformations which could have caused the collapse of the overhanging roof.

Three-storey building under construction in Van Nuys On Sepuvelda Boulevard near Victory Boulevard in Van Nuys, $8 \mathrm{~km}$ southeast of the epicenter, a three-storey building was under construction when the earthquake struck. Only the first floor slab was poured at that time. In the north-south direction, the frame was three bays wide with the center bay being a moment resisting frame. Single-bay inverted V chevron bracings were provided along the north and south exterior walls for resisting lateral loads in the other principal direction (Fig. 12). The bracing bays were $10 \mathrm{~m}$ wide and the storey height was approximately equal to $3.6 \mathrm{~m}$.

The structure did not suffer any significant damage, although the ground shaking was particularly strong in that area. However, all bracing members at the first floor experienced significant inelastic out-of-plane buckling (Fig. 13). As shown, both braces were permanently deformed in the
Fig. 13. Three-storey building under construction in Van Nuys: out-of-plane buckling of the first-storey bracing members on the north wall.

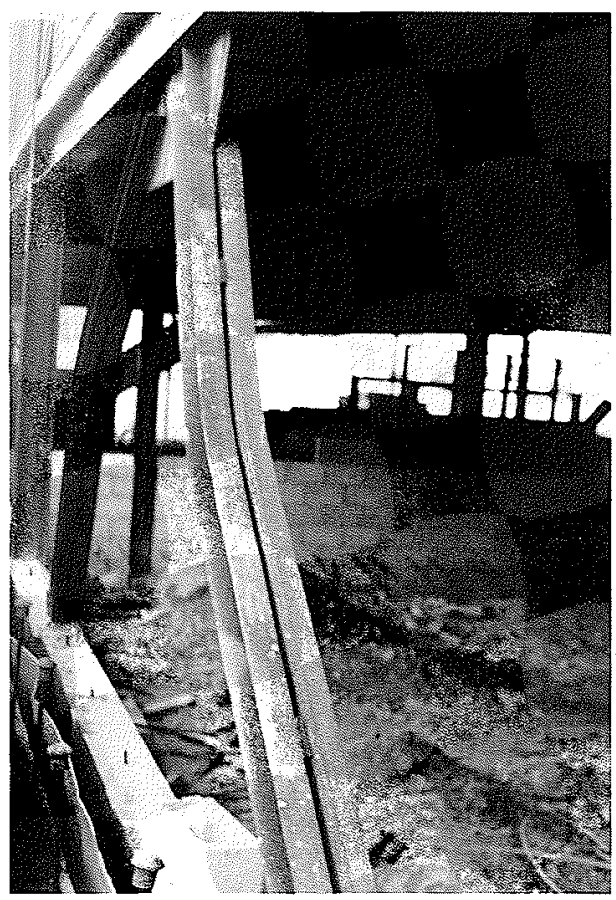

Fig. 14. Three-storey building under construction in Van Nuys: undamaged beams at the second level on the north wall.

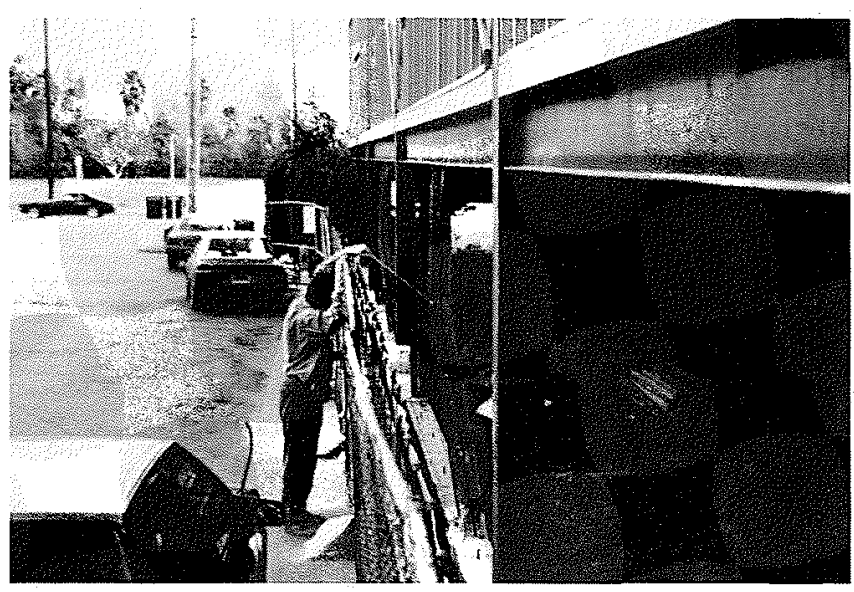

buckled shape, which indicates that both braces likely yielded in tension during the ground shaking. These members were made from back-to-back channels, $152 \mathrm{~mm}$ in depth and $76 \mathrm{~mm}$ in width, assembled by means of $10 \mathrm{~mm}$ spacers at quarter span. Though an unbalanced vertical force likely developed at the apex of the $\mathrm{V}$ at mid-span of the beams, no signs of plastic deformation could be observed along the beams (Fig. 14). The moment resisting frames in the north - south direction did not suffer any visible damage.

\section{No. 2 Brewhouse, Anheuser-Busch Inc.}

The Anheuser-Busch brewing facility is located on Roscoe Avenue in the Panorama City district, southeast of the North- 
Fig. 15. No. 2 Brewhouse, Anheuser-Busch, Inc.: cladding failure on tower structure.

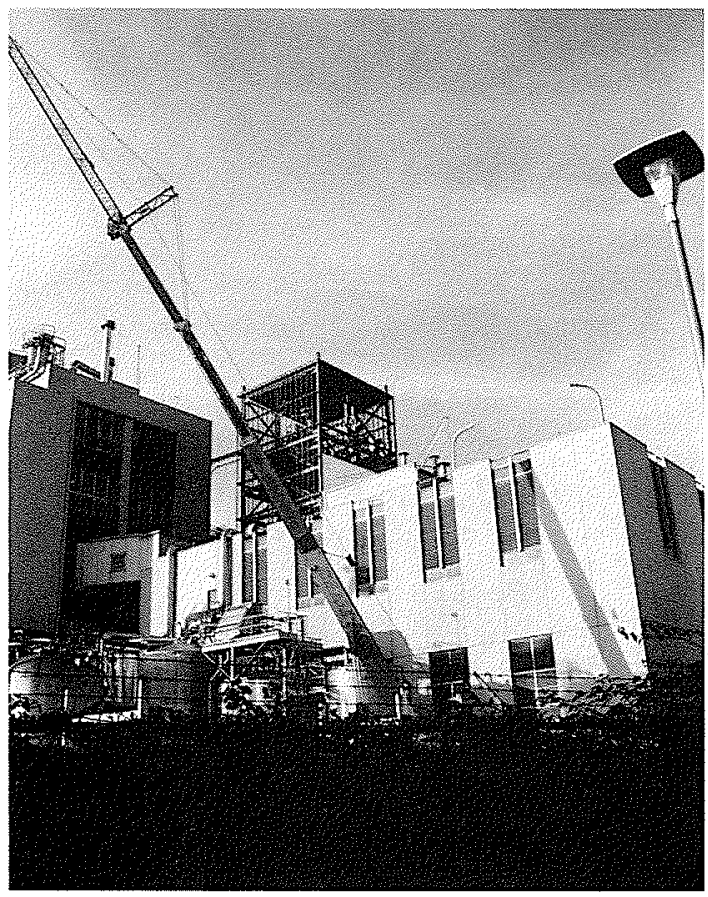

Fig. 16. No. 2 Brewhouse, Anheuser-Busch, Inc.: global view of cladding failure on warehouse.

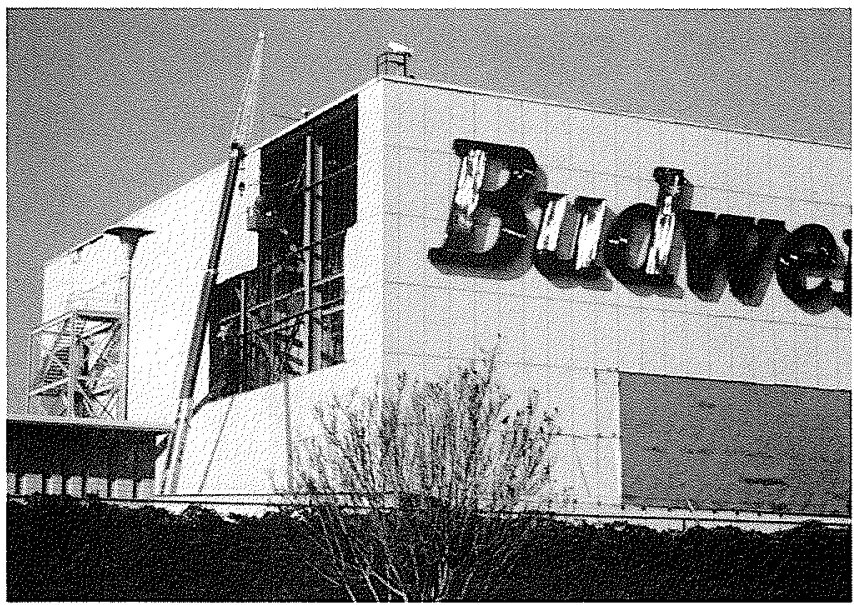

ridge epicenter. Significant shaking at the plant was experienced by personnel during the main shock and aftershocks. The No. 2 Brewhouse is a four-storey concentrically braced structure incorporating wide flange shapes as bracing members. An additional five-storey mechanical tower structure was located on the east end of the brewhouse roof. Significant cladding loss and damage occurred on the tower section of the brewhouse, and other warehouse structures located at the plant experienced similar problems (Figs. 15-17). In addition to the cladding failure, several double angle chevron bracing in the tower portion had buckled (Fig. 18).

It was learned that the plant had been undergoing a seismic upgrade program for several years. This retrofit program coupled with the highly redundant structural lateral load resisting system are responsible for the generally good
Fig. 17. No. 2 Brewhouse, Anheuser-Busch, Inc.: close-up view of cladding failure on warehouse revealing steel braced frame.

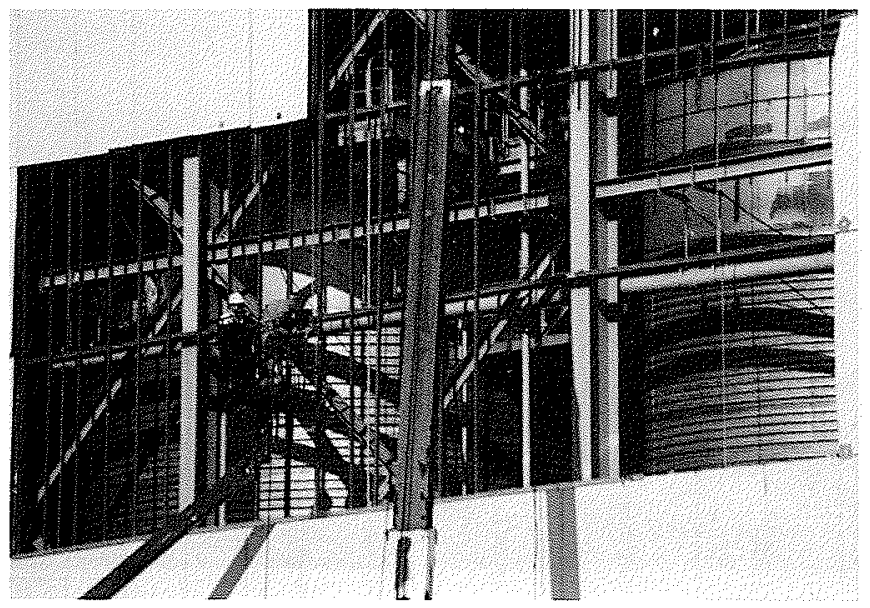

Fig. 18. No. 2 Brewhouse, Anheuser-Busch, Inc.: buckling of double angle chevron bracing in the tower portion.

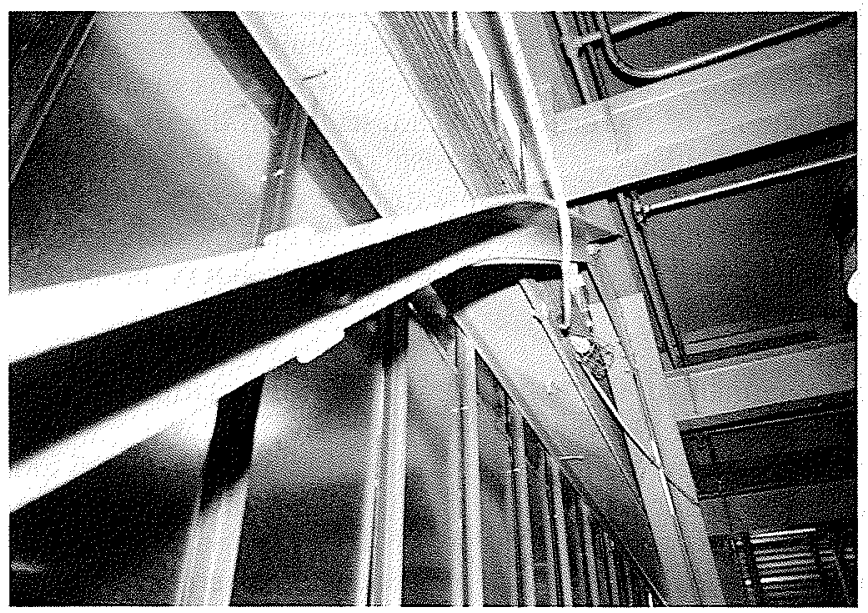

response of most of the plant structures, considering its close proximity to the epicenter. The mechanical processing equipment housed within some of the buildings suffered significant damage, resulting in down time for their repair, realignment, or replacement.

\section{Asphalt and rock plant}

An asphalt and rock planted located some $15 \mathrm{~km}$ from the epicenter in the Sun Valley district was visited. The plant contained numerous gallery and truss structures, some dating back to the 1900 s, with the latest major expansion of operations completed in 1964 (Fig. 19). Many of the steel frames have undergone something of a cannibalization process during the course of years of regular maintenance and modification programs. Portions of the plant were originally designed for approximately $0.1 \mathrm{~g}$ lateral forces. The generally undamaged 1964 expansion was designed for $0.18 \mathrm{~g}$ lateral loads coupled with meticulous structural design which determined the period and stiffness for each independent braced framed structure. Because it is a gravel quarry and an active, on-site production facility, the plant is founded on very deep, stiff, 
Fig. 19. Asphalt and rock plant: typical conveyor and truss system.

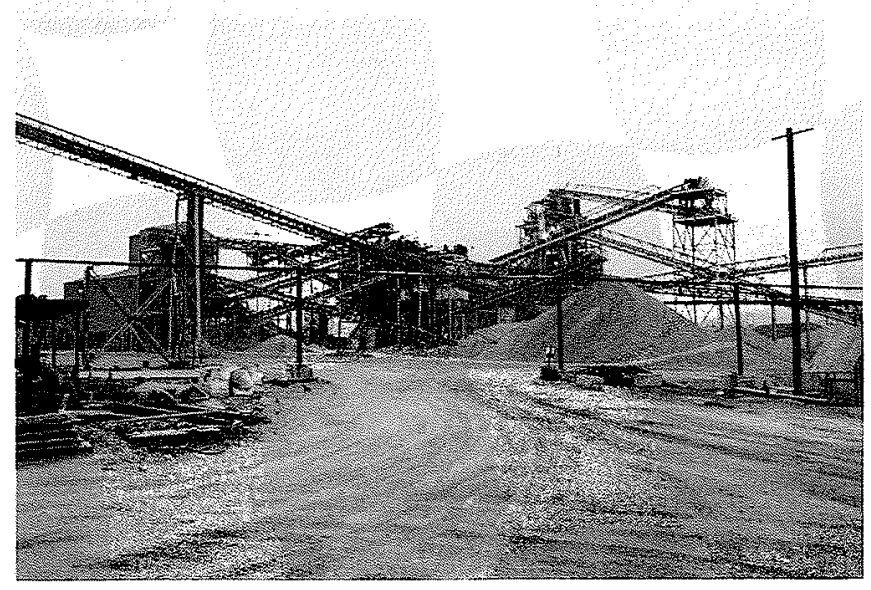

alluvium deposits with boulder inclusions.

There were no gallery, tower, or conveyor collapses at this site even though the shaking was reported to have rattled the structures intensely. Some evidence of elastic deformation in the bracing as well as minor foundation cracking at column braces were also reported. Numerous anchor bolt elongations of the order of $3 \mathrm{~mm}$ had been discovered and one $19 \mathrm{~mm}$ diameter anchor displayed a tensile brittle fracture. Remains of this bolt were discovered some $60 \mathrm{~m}$ away. Overall the plant sustained only nominal damage. After rectification, it was operational within four hours of power resumption.

\section{Department of Water and Power San Fernando Generating Station}

A $350 \mathrm{MW}$ generating station, located approximately $15 \mathrm{~km}$ from the epicenter, again in the Sun Valley district, was also visited. It had been reported to have experienced intense shaking. This facility came on grid as the emergency power source following disruption to the electrical service caused by the main shock of the earthquake. The plant's boilers are fuelled by natural gas and are each supported by separate sixstorey concentrically braced framed structures (Fig. 20). Plant personnel reported essentially no structural damage. It is interesting to note that the $70 \mathrm{~m}$ high stacks constructed of redwood cedar with stucco finish and brick lining also remained free of damage. A $24 \mathrm{~m}$ diameter by $15 \mathrm{~m}$ high domestic water tank, which was nearly full at the time of the main shock, exhibited nominal foundation movement as evidenced by the circumferential cracking in the soil (Fig. 21). This movement resulted in a minor leak in a $50 \mathrm{~mm}$ diameter discharge line.

\section{Four-storey commercial office structure}

An approximately $20000 \mathrm{~m}^{2}$ four-storey office complex (Fig. 22) suffered extreme bracing related fractures and deformations. The building is located at the intersection of Magnolia and Lankershim boulevards in North Hollywood, some $16 \mathrm{~km}$ east of the epicenter. The concentrically braced building was constructed in 1986 according to the 1980 Los Angeles Building Code, which is essentially the same as
Fig. 20. Department of Water and Power San Fernando Generating Station: boiler structures.
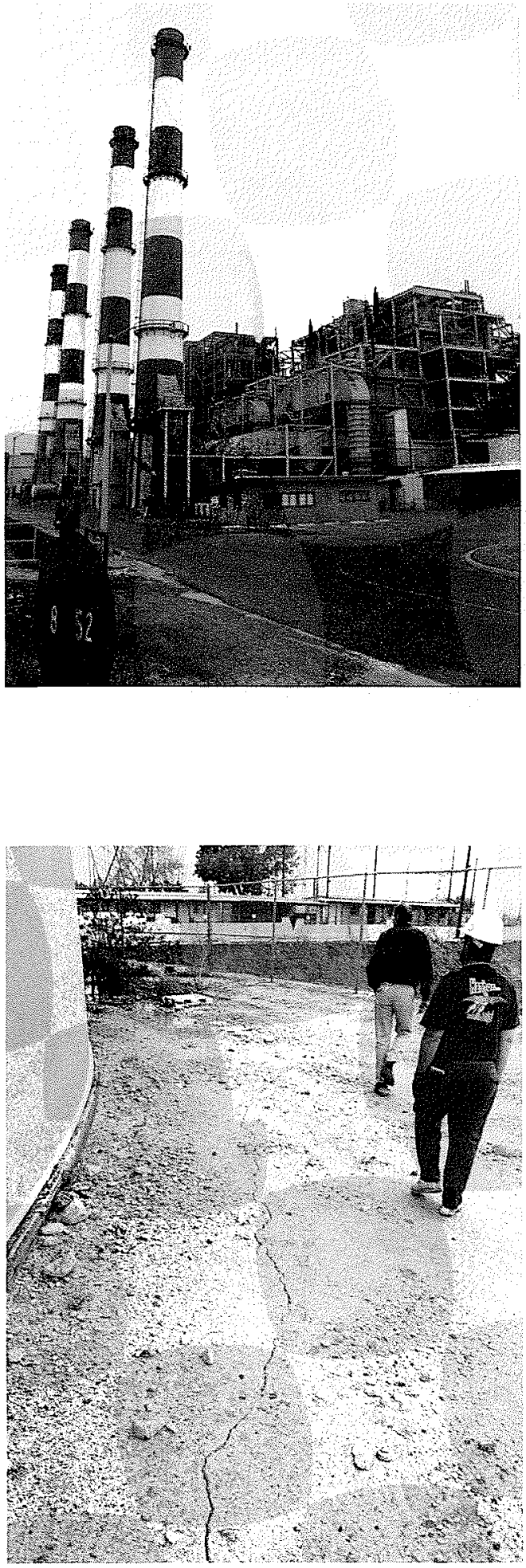

the 1982 UBC code (ICBO 1982). The structure is believed to be founded on deep stiff soils and there were no reported geotechnical related failures in the area. The damage witnessed in the building is attributed only to the strong motion shaking and not to any induced foundation settlement or 
Fig. 22. Four-storey commercial office structure: global view.
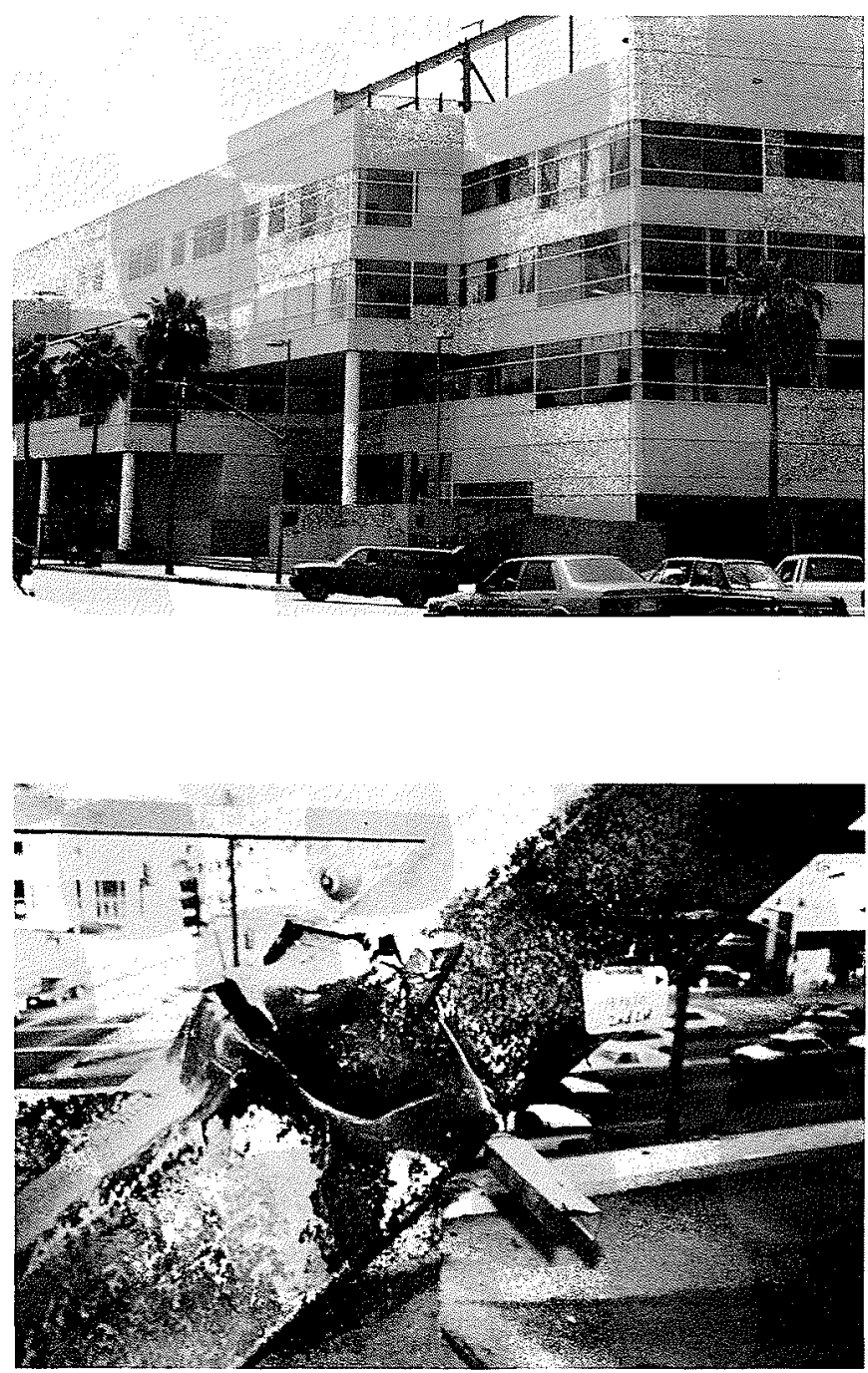

failures. Most of the severe damage was limited to the north - south oriented braced bays at the second floor. This potentially implies that the demand-to-capacity ratio of the braces was somewhat higher at the second floor (Bonneville 1994) and that the existing chevron braced system was not capable of redistributing forces to other levels after the second-storey failures occurred. Significant ductility problems were exhibited in the HSS $305 \times 305 \times 9.5 \mathrm{~mm}(12 \times$ $12 \times 3 / 8$ in.) tubular braces. Many of the failures found were attributed to local plate instability of the section because of the high width-to-thickness ratios of the walls of the steel tubes. Local buckling was isolated to either the end connection or the center of the brace (Figs. 23 and 24). Ruptures in the braces were caused by high stress, low cycle fatigue resulting in the formation of a brittle crack at crimped wall failures from local instability. One brace had ruptured completely through its cross section (Fig. 25).

One braced frame failed at its slotted welded connection to the gusset (Fig. 26). At another location within the structure, where the bracing was discontinuous or offset and a special moment connection was required, the resulting
Fig. 24. Four-storey commercial office structure: local failure of hollow structural brace at center.

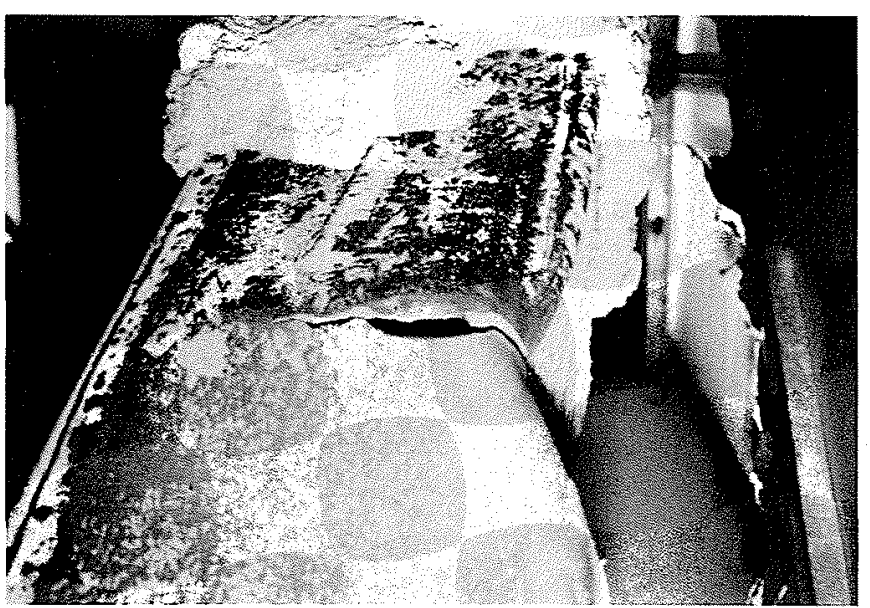

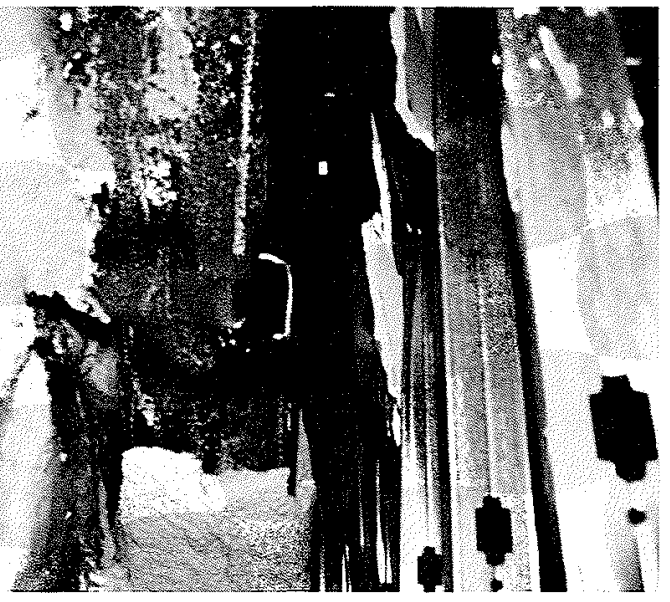

deformations initiated the fracture of a full penetration weld connecting the girder to column flange (Fig. 27). Intense outof-plane buckling of the braces initiated precast facia panel damage. Even for this extreme loading condition, however, the panels performed well and none became detached from the structure. There was also some permanent deformation in girders from in-plane bending due to frame behavior and torsion due to brace buckling during the earthquake.

The building remained plumb following the earthquake, although there was strong evidence of a second-storey drift of at least $5 \mathrm{~mm}$. In retrospect, of the significant damage found at this building, the initial assessment of the structure by the owner's representative prior to the review engineer arriving on site was that the structure had not sustained much damage (only one window had been broken). Only after the preliminary assessed cosmetic damage to the dry wall was removed, at the order of the engineer, was the extent of damage revealed and proper assessment of the structure could begin.

Even though the failures did not jeopardize the vertical load carrying capacity of the building, the extent of damage 
Fig. 26. Four-storey commercial office structure: failure at slotted gusset connection.

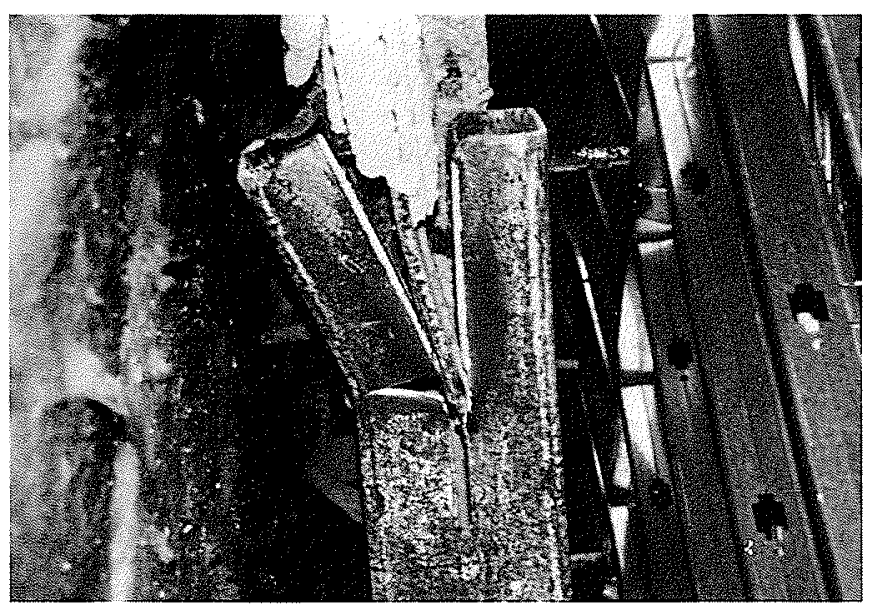

Fig. 27. Four-storey commercial office structure: fracture of full penetration weld at girder flange.
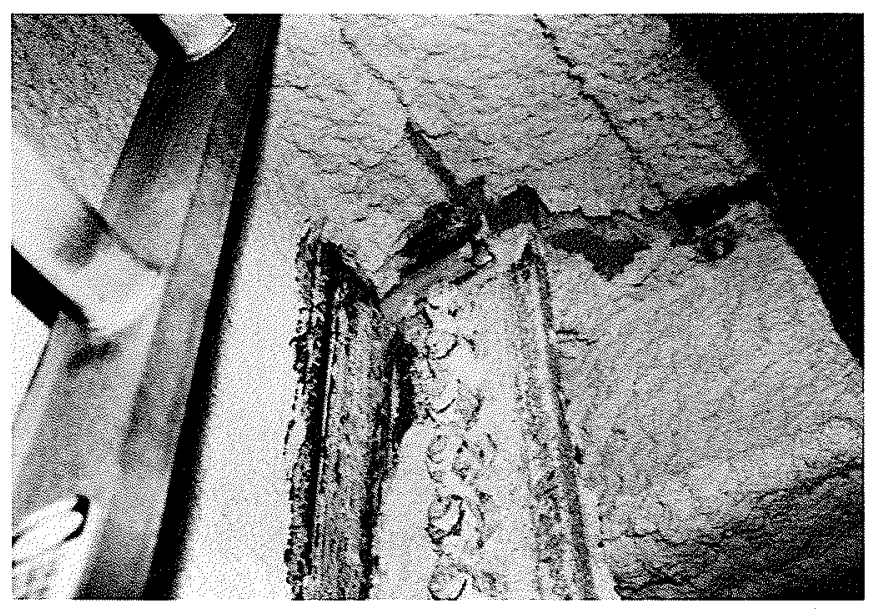

to the lateral load resisting system fully justified the imposition of a "limited entry" restriction, not allowing continued occupancy. Upon revisiting the building three months after the main shock, the structure had been stabilized using temporary bracing and repair was under progress. The retrofit scheme that was adopted features interesting aspects worth discussing in the following.

A review of the structure by the inspecting consultant indicated that the structure had conformed to the code intents for its period of construction. In the 1980 Los Angeles code, however, neither brace connection strength requirements nor additional strength criteria were recognized. Typically, concentrically braced frames built at that time would classify under the aforementioned ordinary braced frame category for which little or no attention was paid to ductile detailing or capacity design concepts. Therefore, repair solutions had to recognize this potential for less ductile failures, and avoid local overstrengthening without carefully considering the severe impact this may have on the rest of the structure.

For example, introducing overly strong new braces into this structure would have possibly ensured elastic brace behavior, but risked buckling of the columns in the bracing
Fig. 28. Four-storey commercial office structure: newly installed wide flange braces and gussets.

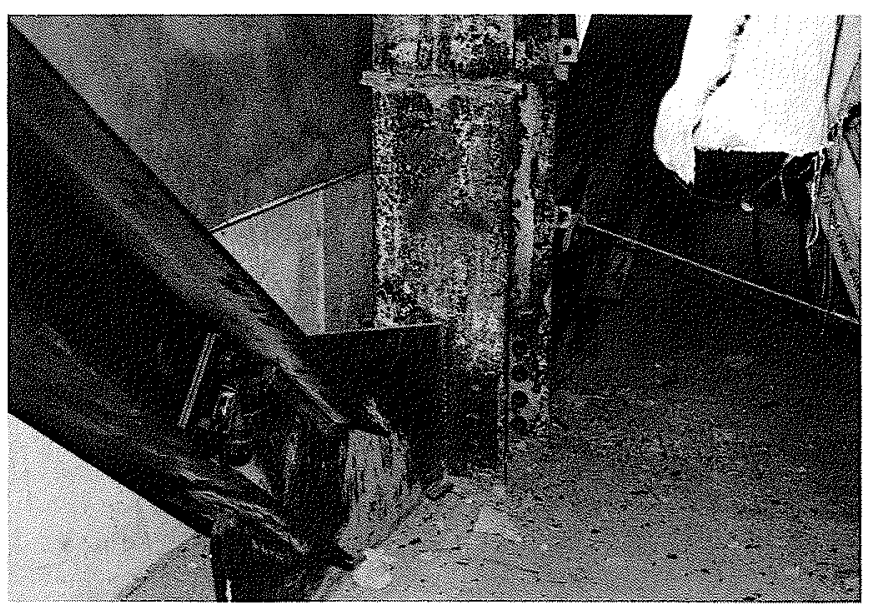

Fig. 29. Four-storey commercial office structure: close-up view of new gussets at brace end for corner columns.

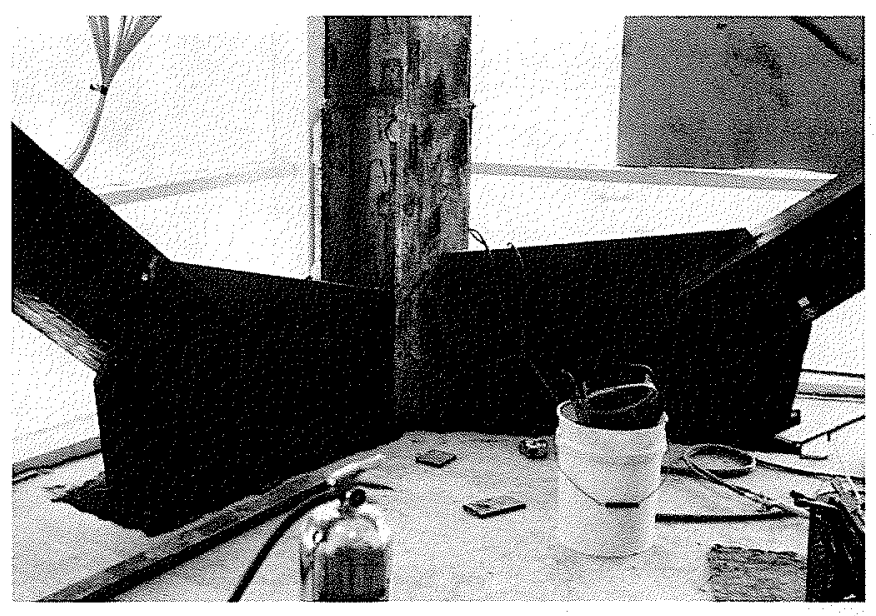

bents during future earthquakes. Such seismic structural behavior would have been far less desirable than the actual performance during the Northridge earthquake. Thus, all braces throughout this building were replaced by new $350 \mathrm{~mm}$ deep wide flange members (Fig. 28). These elements have a global buckling strength close to that of the original members but meet all the seismic design ductile detailing requirements specified for special concentric braced frames in the U.S. (e.g., AISC 1992). These requirements are essentially identical to those for ductile braced frames in the S16.1 Canadian standard. Attention has also been devoted to brace connections. The sizeable gusset plates, typically designed to be stronger than the brace members in special concentric braced frames, are noteworthy (Figs. 28 and 29).

In order to better distribute the ductile behavior to all stories of the building, vertical members were added to tie all chevron braces together over the height of this building (Fig. 30). As such, to the authors' knowledge, this represents the first implementation of the "zipper" system developed a few years ago by Khatib et al. (1988) to remedy the deficiency germane to chevron braced frames that have a tendency to concentrate seismically induced inelastic response 
Fig. 30. Four-storey commercial office structure: newly installed braces in repaired inverted chevron-type braced-frame with vertical tie-members added to implement “zipper" system.

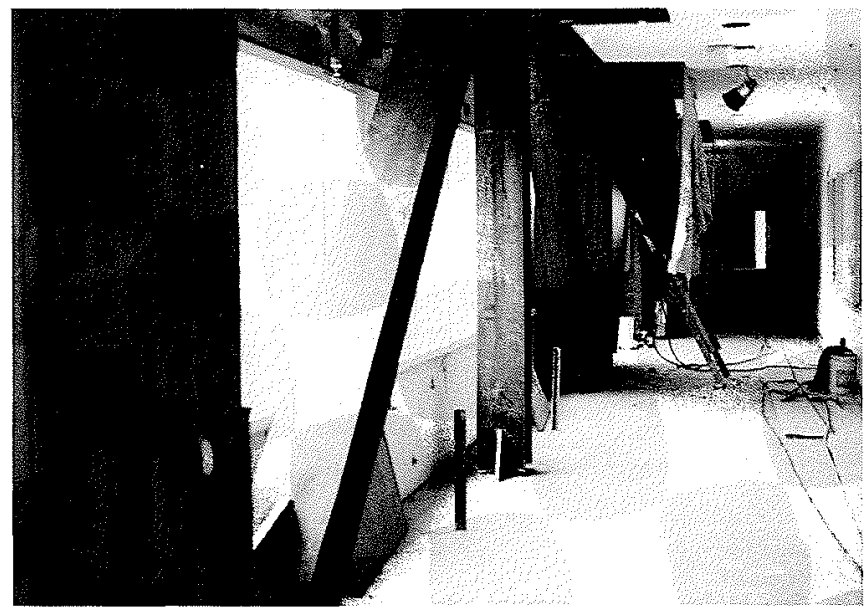

only in one or a few stories. During the retrofit analysis, the effect of moment connections at the beam-column-brace intersections was also investigated. It was discovered that significant improvement to post-buckling performance of the frames could be obtained through the transformation of simple connections into moment joints in the repair areas. Therefore this approach was also implemented in the retrofit.

\section{Two-storey fashion plaza}

A commercial redevelopment project incorporating the interesting features of an existing steel framed theater complex was constructed circa 1970 to become a fashionable plaza. This two-storey steel framed building, including underground parking, is located on Ventura Boulevard in the Sherman Oaks district. From a review of available drawings with the owner's representative, it became apparent that the structural system erected differed substantially from the reinforced concrete and wood frame structure originally planned. The lateral load resisting system consisted of several bracing systems in each orthogonal direction. The eastern section incorporated both chevron hollow structural section bracing and wide flange concentric bracing in each bay orientation. For the western section, the retail building contained moment resisting frames in each structural direction.

Damage observed at this structure included longitudinal cracking in the concrete slab cast on light gauge steel decking likely related to diaphragm action. This was particularly evident in the rear parking area at street level along the beam lines (Fig. 31), but was also witnessed at the second floor level of the plaza. Tension and shear failures of two corbels supporting beams were also discovered in the lower parking level (Fig. 32). Nominal overall member buckling had occurred in an exposed wide flange brace at the rear of the structure (Fig. 33).

Very little nonstructural damage and chaos occurred in the merchant area braced with the tubular chevron bracing albeit these areas were void of suspended ceiling and other architectural finishes, whereas severe nonstructural damage occured in the moment resisting framed areas of the structure
Fig. 31. Two-storey fashion plaza: cracking along beam lines in parking deck.

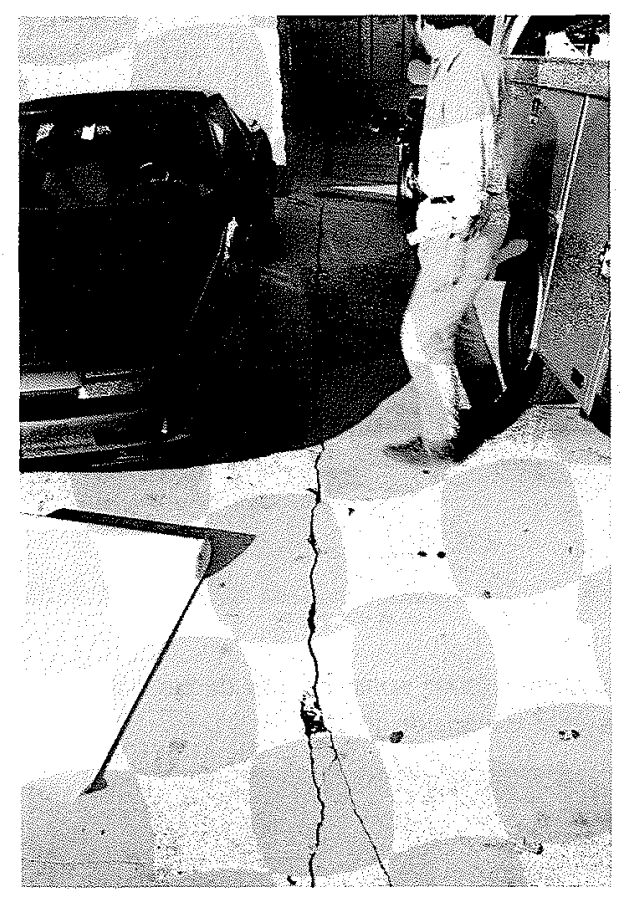

Fig. 32. Two-storey fashion plaza: beam anchorage failure at corbel.

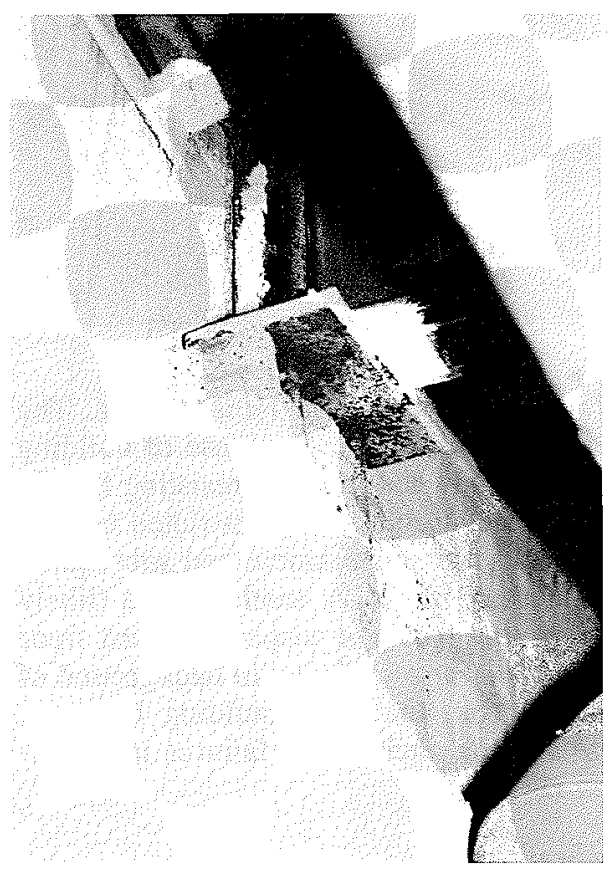

although the frames did not exhibit any damage themselves from initial observations (Fig. 34). At the former theater section, a steel framed sign structure suffered bolt shear failures at the column splice locations at the second floor, necessitating its subsequent removal for hazards mitigations (Fig. 35).

\section{Holy Cross Hospital administration building} This facility is a three-storey reinforced masonry and steel 
Fig. 33. Two-storey fashion plaza: slight overall member buckling of wide flange brace.

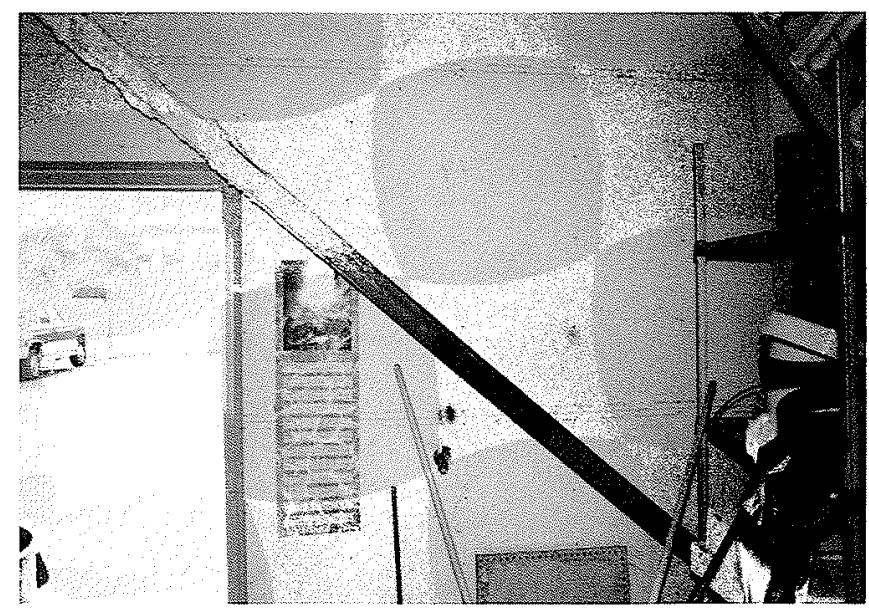

Fig. 34. Two-storey fashion plaza: nonstructural damage in moment framed areas near expansion joints.

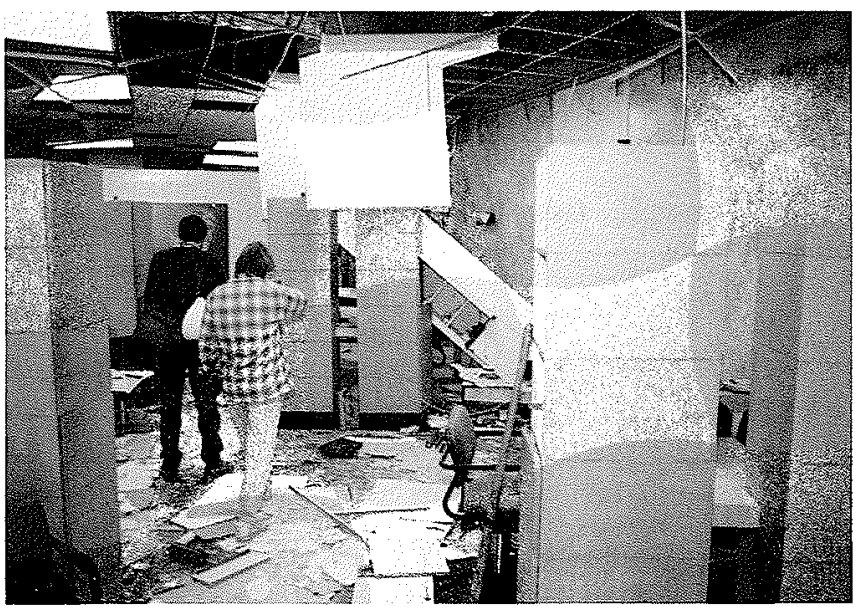

framed building located in the Mission Hills district. The street bracing system was not identified because of building finish cover but possibly contained moment resisting frames in some areas. Entry to the structure was restricted to only record retrieval following initial assessment and subsequent decision for its future demolition. A steel framed (likely diagonally braced) elevator shaft and suspended third floor walkway (behind stair tower and walkway in background of Fig. 36) had separated from the main building by some $200-250 \mathrm{~mm}$ due to column anchor bolt failures in a reinforced masonry wall (Fig. 37).

\section{Van Nuys office building}

A five-storey office structure located in the Van Nuys district suffered significant damage. Concrete-encased steel moment resisting frames for the north - south and east-west orientations of the building layout provided the lateral load resisting system. The building was essentially plumb following the earthquake; however, facade failures were apparent, most obvious at the east and west end walls of the structure (Fig. 38). The east end wall was constructed of a double
Fig. 35. Two-storey fashion plaza: sign frame anchorage shear failure in the former theater portion.

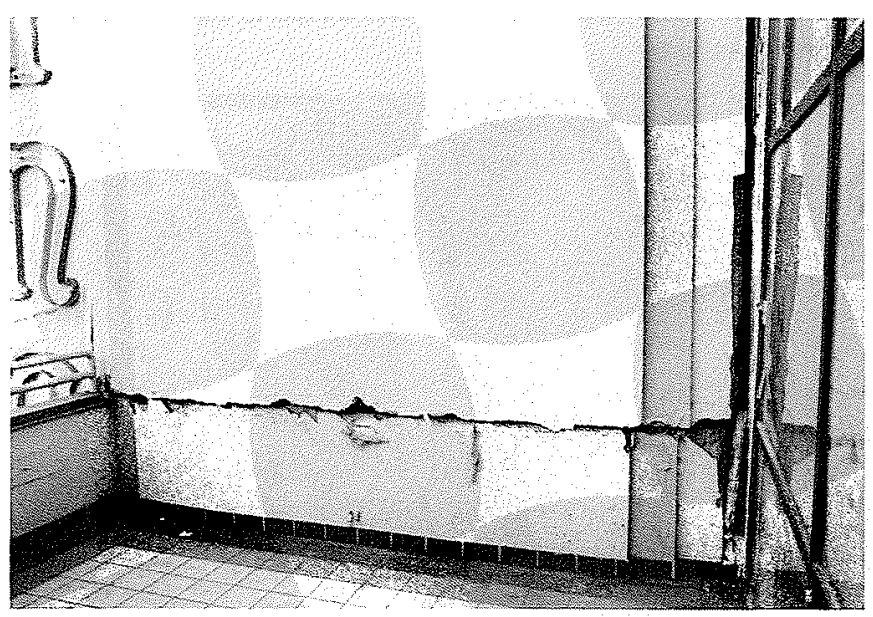

Fig. 36. Holy Cross Hospital administration building: elevator and suspended walkway in background.

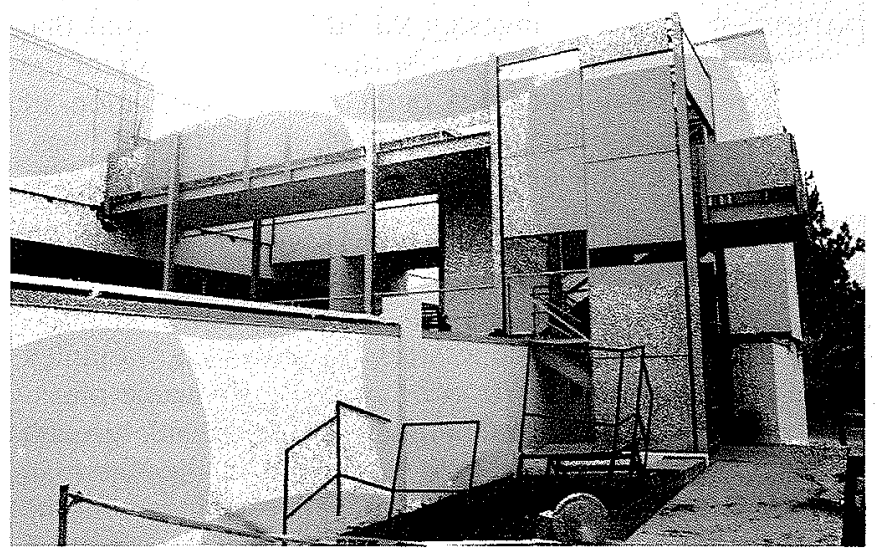

wythe of solid masonry brick with nominal reinforcing in the cavity between the wythes. This end wall was very similar to the one in the Kaiser Medical Building which suffered a complete second storey collapse on Balboa Avenue (Mitchell et al. 1995).

The separation of both the end wall and stair tower is attributed to dowel shear failure between the floor slabs and the end facade walls. The end wall's collapse mechanism is surmised to have been initiated by shear failure at the base followed by bearing loss, allowing the remaining wall to vertically shear and slide down the face of the structure. Concrete spalling was apparent at the top flange-slab locations as well as in the beam-column joint regions. Physical separation of the aluminum and glass south curtain wall was evident at the second floor level.

\section{Moment resisting frame under construction}

The steel building shown in Fig. 39 is located in Santa Monica and was under construction at the time of the main shock. It had apparently survived the earthquake intact. However, after reading a news story about steel failures discovered 
Fig. 37. Holy Cross Hospital administration building: elevator shaft column anchorage failure.

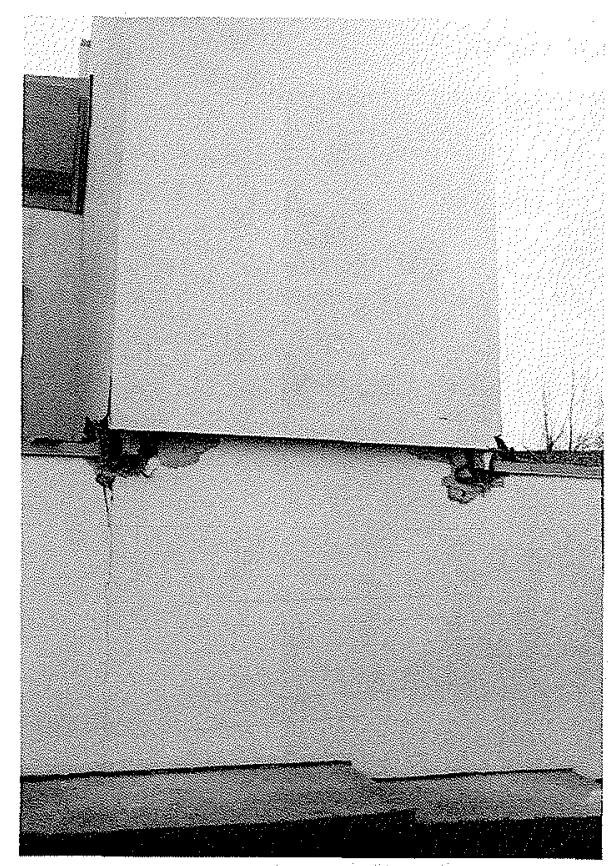

Fig. 38. Van Nuys office building: end wall failure on east face of building.

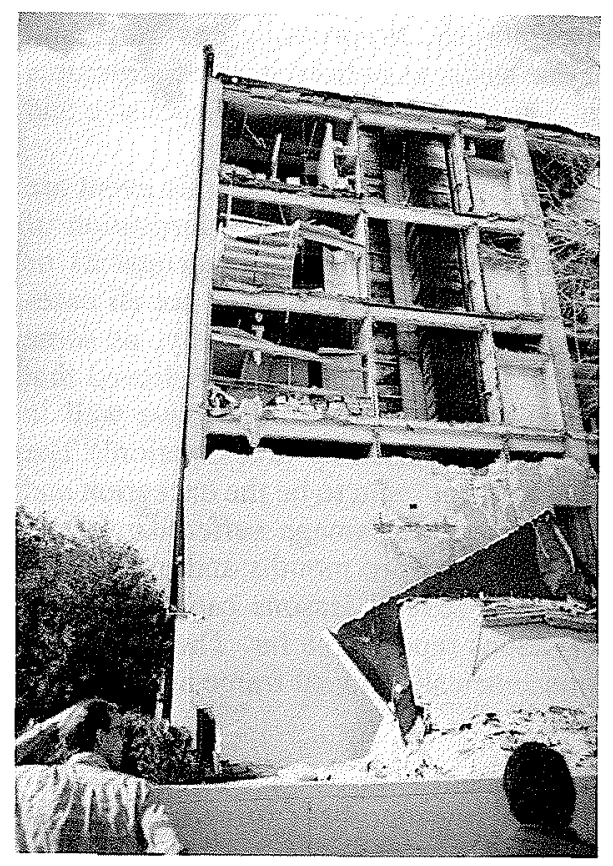

elsewhere, the contractor decided to randomly inspect a few beam-column connections by removing the fireproofing installed prior to the earthquake. Nearly all joints of the moment resisting frames located on the north side of the building were found to have severe fractures.

Examples of the fractures in this building are shown in Figs. 40-42. Typically, at a damaged connection, the column fractured at the level of the full-penetration weld of
Fig. 39. Moment resisting frame under construction: north facade along which beam-column connections suffered cracking and fractures.

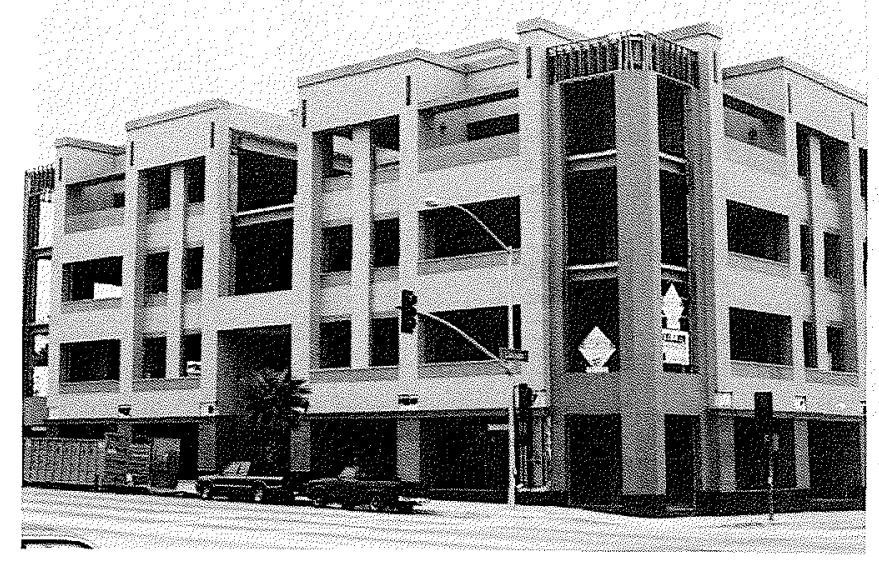

Fig. 40. Moment resisting frame under construction: typical beam-column connection damaged by column cracking and fracture at the level of the beam's lower flange weld.

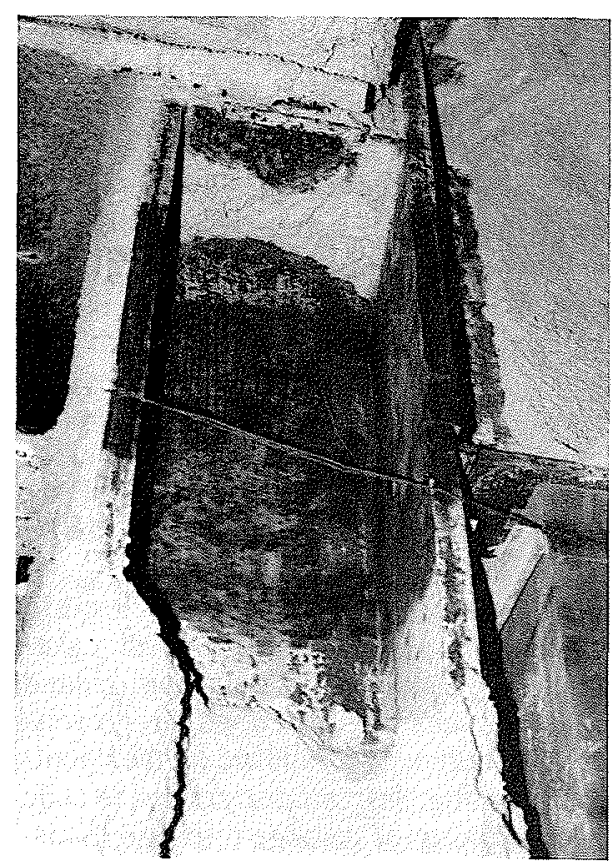

the beam's lower flange, and cracking propagated into the column's web a short distance horizontally, then mostly vertically and toward the other flange weld of the same beam.

The web of the column of Fig. 42 also fractured although this is not visible on the photo. Clearly, since the building was under construction at the time of the earthquake, this damage cannot be attributed to causes other than the Northridge earthquake.

Although a single case study of beam-column connections having suffered cracking or fractures is presented in this paper, this type of brittle failure occurred frequently throughout the Los Angeles area. In May 1994, similar damage had 
Fig. 41. Moment resisting frame under construction: close-up view of the fractured column shown in Fig. 40.

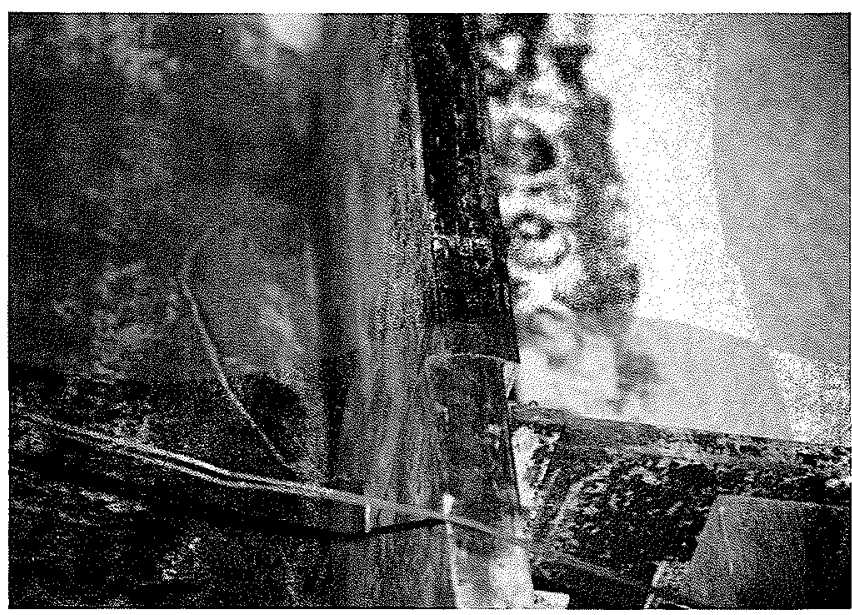

been discovered in more than 60 buildings further to thorough postearthquake structural inspections (M. Engelhardt, 1994, private communication). As of November 1994, it was believed that possibly hundreds of steel moment resisting frames have suffered brittle joint failures in the Los Angeles area (Ross and Mahin 1994).

\section{Discussion}

Steel ranks very high among structural materials suitable for earthquake resistance. It exhibits high strength and stiffness as well as good ductility and toughness. Its strength-toweight ratio is also remarkably high. When compared to that of other common materials, the behavior of steel is rather well defined and understood and a high quality can be achieved by the in-shop prefabrication of all components of steel frames. This makes the seismic performance of steel structures more predictable than that of other construction systems. Moreover, after an extreme event, damaged components can be easily repaired or replaced.

However, building with steel is not sufficient by itself to warrant a proper performance during a strong earthquakeinduced ground shaking. The characteristics of future ground motions are highly uncertain and the prescribed design seismic loads are considerably reduced by reliance on the ductility of material, which means that designing structures to code does not preclude the possibility of damage to occur. Satisfactory behavior can only be achieved if a sound structural arrangement is provided and if the structural elements and their connections are sized in such a manner that appropriate means of absorbing and dissipating energy exist and premature failures are avoided, especially within the gravity load resisting system.

Except in case of collapse, earthquake-induced damage to steel frames, even serious and potentially catastrophic, is generally less apparent and thus more difficult to detect and assess than in other types of construction. The framework is most often hidden and because damage is usually constrained to a very limited portion of the structure (connections, local buckling, anchor bolts, etc.), thorough inspection is needed to obtain an overall and realistic assessment of the damage.
Fig. 42. Moment resisting frame under construction: close-up view of a beam-column connection damaged by column flange fracture at the level of the column web stiffener (left) and beam's lower flange (right).

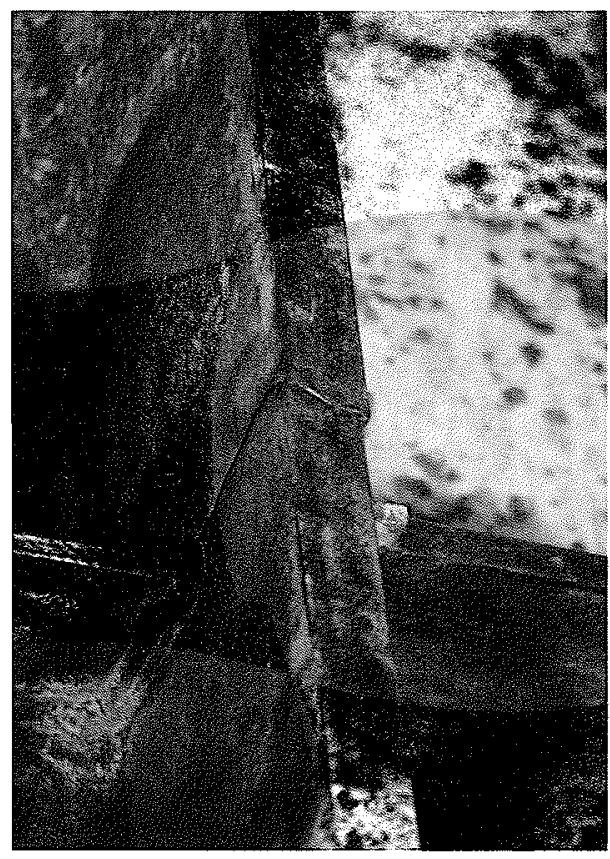

For building structures, detailed inspection requires the removal of architectural finish, fireproofing covering, and even portions of concrete slabs, as noticed in some structures visited in Northridge. This makes the process expensive and lengthy.

Data obtained in the early stages after a seismic event are then fragmentary. As owners proceed with examination of their structures, additional information on inadequacies or failures is continually reported. Unfortunately, not all cases are made available to the engineering community, as some information is kept confidential. (In fact, it is believed that even the perception that steel constructions behave well in earthquakes can be somewhat biased by this situation!) The Northridge earthquake does not seem to be the exception and it appears that the full extent of damage suffered by steel structures will not be known before months and even years have passed. Nevertheless, several lessons can already be drawn from the observations reported so far. These are next summarized for the concentrically braced frame and moment resisting frame systems.

\section{Inelastic response of bracing members in concentrically braced frames}

The numerous occurrences of severe brace overall buckling and tension yielding which were observed during the reconnaissance visits stress the importance of properly detailing bracing members in concentrically braced frames for which a ductile behavior is required for earthquake resistance. In particular, the need for preventing local buckling and subsequent premature failure of the braces at the plastic hinges has proven to be mandatory. This problem is more acute for rectangular tubular bracing members and had already been rec- 
ognized for some time (e.g., Liu and Goel 1988).

Observations after the Northridge earthquake also indicated that engineers should be aware that inelastic buckling of braces may create additional problems. For example, out-ofplant buckling of braces represents a serious damage potential for cladding, partitions, or mechanical equipment in buildings. Even though such damage may not impair the integrity of the structure, it may be highly hazardous for its occupants (e.g., downfall of glass debris, masonry blocks, or precast panels) and thereby should be considered in full as an ultimate limit state in earthquake-resistant design (Knoll 1993). Breakage of mechanical equipment or collapse of walls may also have serious impacts on the postearthquake functionality of a building, which can be a serious matter of concern for building owners or users, or business survival.

This problem is somewhat accentuated by the fact that most designers favor out-of-plant, rather than in-plane, buckling for bracing members. Indeed, a plastic hinge can easily be accommodated within the gusset plates in the out-of-plane buckling mode when following the design recommendations proposed by Astaneh et al. (1985). Moreover, out-of-plane buckling can be easily achieved for any brace section. Hollow structural section square bracing with standard connections and $\mathrm{W}$ shapes with the web in the vertical plane tend to naturally buckle out-of-plane, whereas out-of-plane buckling of double angle bracing can be readily obtained by properly sizing the section.

Damage can, however, be easily prevented by providing sufficient free space along each side of the braces or, alternatively, by forcing the bracing members to buckle in-plane.

Bending moments that develop at the ends of bracing members upon buckling can also create some problems by overstressing the connections and the surrounding structural elements. In the Northridge earthquake, the case of beams being permanently distorted in torsion as a result of the outof-plane buckling of bracing members is an example of such undesirable behavior. These secondary bending moments must be resisted by adjacent connections and members, in addition to the primarily axial loads likely to build up in the braces, and must therefore be accounted for within an appropriate capacity design procedure, as described in the next section.

Alternative ways of dissipating energy in braced frames have recently been proposed (Cheng et al. 1993; Tremblay and Stiemer 1993) and could eventually represent promising solutions for overcoming some of the shortcomings associated with inelastic buckling of bracing members.

\section{Capacity design of concentrically braced frames}

Numerous failures and evidences of inelastic response were observed by the authors in elements other than the bracing members along the lateral load path of concentrically braced frames. These occurred as cracks in floor diaphragms, failures of brace connections, torsional deformations of beams, and tensile fracture of anchor bolts or base plates. Many of the failures observed were brittle in nature.

Similar behavior has also been reported for many other braced structures not visited by the Canadian reconnaissance team. For instance, a riveted steel structure, part of a batch plant constructed in the early 1950s and located within 6$8 \mathrm{~km}$ from the epicenter, exhibited various kinds of tension failures in its braces (G. Hichborn, 1994, private communication). Failure modes included complete tensile fracture of two braces at their connections, serious tearing and deformation in most angle clips, partial plate pull through of rivets, and permanent elongation deformations of remaining braces.

Another nearby structure, also several decades old, was constructed as stacked framing modules. Each module contained four columns with connection flanges at their ends and incorporated seismic cross or knee bracing. This structure experienced column flange bolt failure in single shear. The four bolts failed completely in all of the first level column splices. Shearing between the first and second level modules was accompanied by severe horizontal translation. Luckily, this movement was stopped by a heavy walled water supply pipe running up one of the columns. Further motion would have resulted in catastrophic failure of the fully loaded structure. In addition, many of this plant's foundation anchors failed in combined tension and shear, while others deformed significantly by elongation.

This broad range of failure types illustrates very well how arbitrary and uncontrolled the seismic performance of concentrically braced frames can be when a comprehensive capacity design has not been applied thoroughly. During a strong ground shaking, the most overstressed element in the as-built lateral load resisting system reaches invariably its capacity first. Because braced frames inherently exhibit very low redundancy, this overstressed element would have to undergo substantial inelastic deformation prior to subsequent redistribution, if any, of forces to other elements. Failure of the element may then occur early in the earthquake if it does not possess sufficient toughness to absorb the energy fed into it by the ground motion.

Such behavior would be typical of ordinary braced frames. Although higher seismic loads are prescribed for that system, they still represent only a fraction of the loads that would be expected in a structure responding elastically to the design base earthquake ( $40 \%$ when comparing the elastic and design 1990 NBCC base shears). Thus, some degree of inelastic response is still anticipated in ordinary braced frames and premature failure is probable if the weakest element does not exhibit enough ductility. This could be the case, for instance, of concrete roof and floor diaphragms or welded connections. Anchor bolts are also prone to early failure as the demand on these elements can easily exceed their capacity to absorb energy.

Many of the braced frames damaged during the Northridge earthquake were rather old and most likely belonged to the ordinary braced frame category. Despite the higher seismic design loads prescribed for these braced frames, they still remain popular today in seismically active regions because they require less stringent seismic detailing provisions. Braced frames with some degree of ductile detailing were also found to have behaved in a similar uncontrolled manner in Northridge; that is, exhibiting inelastic action or failures away from the braces. This was the case, for example, for the Oviatt Library Building, built in 1991, or the First Interstate Bank Building retrofitted the same year. In these structures, most likely the capacity check on the damaged elements had not been performed or had not included all the effects that actually occurred during the earthquake. In Canada, this undesirable behavior due to lack 
of capacity check in the original design may occur in any ductile braced frame, since, as mentioned earlier, the design provisions included in the S16.1 standard only apply to the steel framing members and not to other elements of the lateral load resisting system. The secondary bending moments developed at the ends of the bracing members upon buckling is an example of effects that may occur during an earthquake.

Because of the low redundancy of concentrically braced frames, any failure along the lateral load path can severely degrade the stiffness and the strength of the lateral load resisting system. The structure can then experience large horizontal deformations and, ultimately, collapse. As mentioned, all damaged concentrically braced frames inspected survived the Northridge earthquake and its aftershocks. However, the potentially adverse effects that the damage observed could have had on the stability of the structures, had the earthquake lasted longer, strongly suggest that any braced frame should be designed in such a manner that inelastic response be constrained to the ductile elements, namely the bracing members. This means that, desirably, a capacity design philosophy should be implemented for (i) all braced frame categories and (ii) the entire lateral load resisting system, including diaphragms, anchorage to the foundations, and the foundations themselves.

Even though anchorage and diaphragm failure have not been observed in moment resisting frames, the same approach should also be applied to this system for improved seismic performance.

Implementing a comprehensive capacity design approach to column base connections and foundations of concentrically braced frames and moment resisting frames still remains, however, a matter of debate. Some recent investigations (e.g., Filiatrault et al. 1992) have suggested that intentionally allowing rocking of the foundations or inelastic elongation of anchor bolts at the base of vertical bracing bents may not adversely affect the ability of a structure to sustain earthquake ground shaking. Such behavior may, on the other hand, lead to an unacceptable level of horizontal deformations and should be thoroughly analyzed before construction.

\section{Vertical ground motions in the design of concentrically braced frames}

Significant levels of vertical ground motions have been recorded during the Northridge earthquake (Finn and Ventura 1994). Such vertical accelerations are known to be of significance for horizontal cantilevered structures (BSSC 1991) such as the roof covering the bleachers of the football field at the California State University at Northridge. The numerous anchorage failures observed at the base of the exterior columns of bracing bents in concentrically braced frames suggest that these structures could have been also affected by vertical accelerations.

Substantial compressive and tensile axial loads develop in the exterior columns of bracing bents of concentrically braced frames to resist the overturning moment produced by horizontal earthquake ground motion. Indeed, it is not uncommon to have the combination of the gravity loads plus these overturning induced forces governing the sizing of these columns. Obviously, anchorage at the base of bracing bents is mainly provided for resisting that overturning moment. Therefore, it is very much likely that these columns and their anchorage become overstressed under the combined action of the horizontal and vertical ground motions, a situation that probably occurred in Northridge.

Such a combined effect is not explicitly addressed in current Canadian codes. Neither is the effect of vertical accelerations on horizontal cantilevers. Thus, it is suggested that the hazard potential of these two effects be assessed for structures located in Canada and, if deemed of significance, that appropriate design provisions subsequently be implemented in codes.

\section{Nonstructural damage}

Many of the structures visited experienced large interstorey drifts and suffered extensive nonstructural damage. Moment resisting frames, being more flexible than braced frames, appeared to be involved in the more critical situations. In some cases, the extent of damage was such that many injuries and even fatalities could have occurred had the buildings been occupied during the earthquake. Large portions of exterior walls and interior partitions collapsed, glass broke, suspended ceilings and mechanical equipment toppled, etc.

The objective of the NBCC earthquake-resistant design provisions is to prevent not only building collapses but also loss of life. Therefore, as mentioned earlier, hazard potential associated with nonstructural damage should be explicitly addressed at the design stage.

Controlling horizontal drift certainly is a possible avenue in preventing damage in a structure. This can be achieved by increasing the stiffness of the lateral load resisting system. For short period structures, a more appropriate approach would be to increase the strength to limit the drift to a target value. This can be done by using inelastic displacement spectra, as proposed by Priestley (1993).

Nonstructural damage can also be limited by using better construction techniques such as stronger wall attachments or improved suspended ceiling structures. Alternatively, proper structural and architectural detailing can be provided, which can allow the anticipated deformation to take place without failure or collapse due to pounding, tearing, or loss of support. Without doubt, the existence of a good collaboration and communication between the architect and the engineer is also part of the solution to such problems.

Regardless of the approach used, engineers must humbly recognize that a great deal of uncertainty is associated with predicting drift in seismic design. Such incertitude should be reflected in design and details by allowing a sufficient margin of safety.

\section{Connection failures in moment resisting frames}

The brittle fracture of field welded beam-to-column connections in steel moment resisting frames is one of the most significant issue of the Northridge earthquake. The following is a summary of the information available as of November 1994 on this consequential structural damage.

The first connection failures were reported only weeks after the earthquake, mainly in buildings under construction, where finishing and fireproofing materials had not been installed yet, or in buildings exhibiting significant permanent interstorey drifts which indicated that some structural damage had likely taken place. In many cases, however, no apparent sway nor architectural damage could suggest that failure had 
occurred, and the structure was declared safe for occupancy after the initial inspection. Failures in connections were found only after structural engineers, recognizing the significance of the problem, required random inspection of joints in various steel structures, leading to the discovery of more failures and prompting other engineers and owners to act similarly. In other cases, buildings were reinspectd after owners had noticed that damage caused by aftershocks was more important than that produced by the main event. Failures of beam-column connections were then detected which had likely diminished the stiffness of the structures.

Most of the structures that have suffered fractures at beam-column joints had been constructed post-1980 and had been designed as special moment resisting frames, which is the equivalent American designation for the S16.1 ductile moment resisting frame category. It is worth mentioning that frequent design practice is to incorporate these special moment resisting frames for only portions of the available building dimension, usually centrally located on the exterior perimeters. In such an arrangement, one can take advantage of the reduced prescribed seismic loads for ductile moment resisting frames while minimizing the costs associated with the construction of moment resisting frames. However, larger members and connections are required in the bracing bays when compared to structures with more evenly distributed moment connected frames.

Occurrence of damage in Northridge does not appear to have been limited to a given range of building height. A survey presented by Ross and Mahin (1994) indicates that 75 buildings for which a permit has been issued for repair in the city of Los Angeles vary from 1 to 22 stories in height. Ghosh (1994) reports that buildings from 1 to 27 stories have been damaged, the majority being less than six stories high. Sabol (1994) indicates that connection failures in taller structures generally occurred in the upper half to two thirds of the building whereas lower frames were more evenly damaged. The observed failure rate in a building varied from less than $10 \%$ to nearly $100 \%$ of the connections. It was also noticed that failures occurred in both types of construction: buildings with nearly all frames moment connected and structures including only a few moment resisting frames. However, it appears that more buildings of the second type experienced structural damage (Bertero et al. 1994).

All fractured joints were of the welded flange and bolted web type, as shown in Fig. 43. Some had their vertical shear connectors partially welded to the beam web. Each discovered failure had full-penetration weld fractures in the bottom flange, very few had these fractures in the top flange. In all cases, there was little or no evidence that plastic hinging had developed in the beams prior to weld fracture. Some damaged connections also exhibited vertical cracking through the shear connector or shearing of the web bolts. It is believed that this secondary mode of failure developed as the beam rotated relative to the face of the column after fracture of the beam flange weld had occurred.

Figure 44 shows some of the failure modes that have been observed at the bottom flange of the beams. Reports indicate that most cracking initiated in the root pass of the weld, near the steel back-up bar. Type 1 and 2 cracks were very frequent. Failures of type 2 could be readily identified in the field. Type 1 failures can also be detected through visual
Fig. 43. Typical welded flange and bolted web beam-column connection in moment resisting frames.
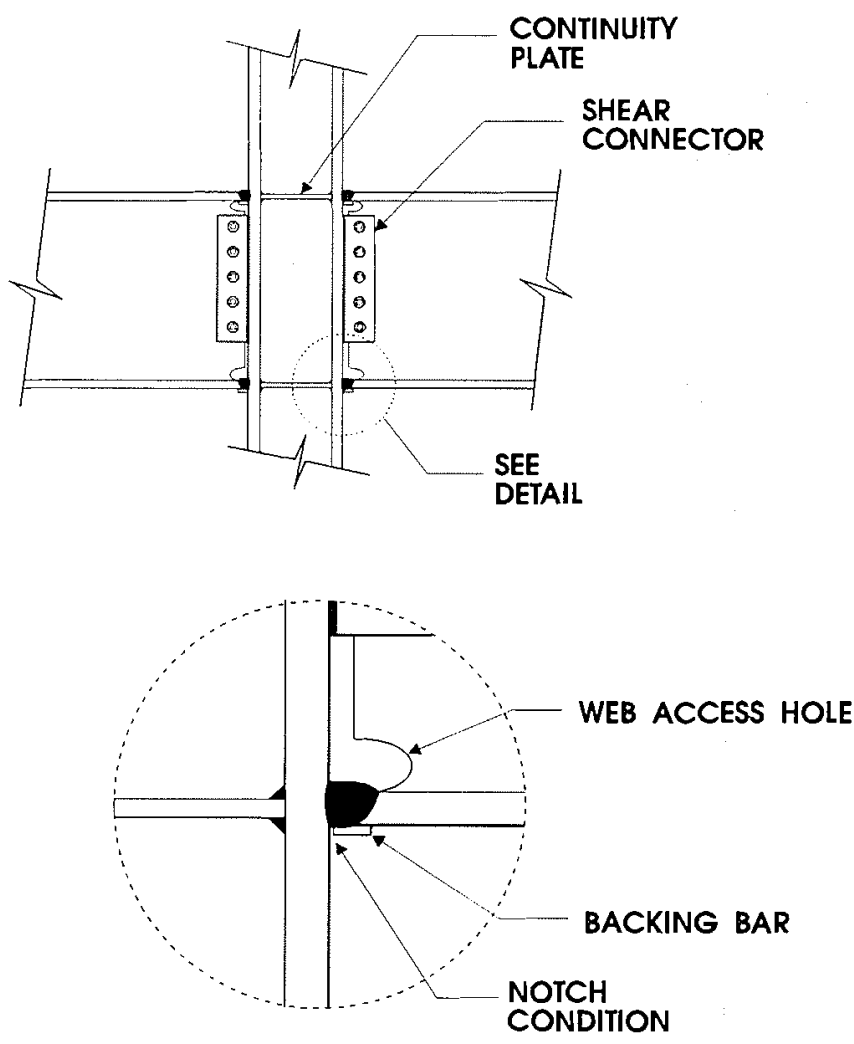

DETAIL

inspection as the backing bar separated from the column face (Miller 1994). Type 3 and 4 failures are similar to types 1 and 2 , but crack propagation took place into the column flange rather than at the interface between the weld and the column flange material. Type 3 cracks can be detected only by means of ultrasonic inspection, as these cracks do not exit the column flange surface.

In other connections, cracks developed across the column flange (type 5) and, in some cases, propagated further into the column web (type 6) (see also Figs. 40-42). Miller (1994) reports that some columns completely fractured horizontally. A few connections also exhibited a crack across the beam flange (type 7) and, according to Bertero et al. (1994), one case of column lamellar tearing (type 8 ) has been reported.

A review of the literature on the experimental research performed in the U.S. and Japan on moment connections in the past 25 years (Bertero et al. 1994) reveals that the seismic performance of welded joint specimens varied from very good to very poor. Indeed, many test programs (e.g., Bruneau and Mahin 1990; Engelhardt and Hussain 1993) had demonstrated that fracture and brittle failures similar to those observed after the Northridge earthquake could occur in heavily welded steel beam-column connections, even when these were constructed in-shop by competent commercial structural steel fabricators, using certified welders and ultrasonic inspection.

For some reasons, these unfavorable results did not make completely their way through the engineering community 
Fig. 44. Typical failure modes in beam flange to column connections (adapted from Bertero et al. 1994; Miller 1994; Ross and Mahin 1994).

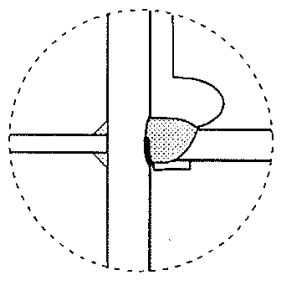

TYPE 1

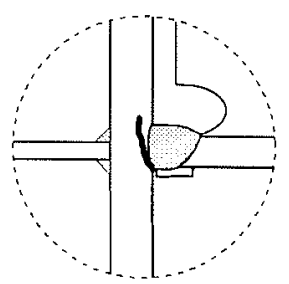

TYPE 3

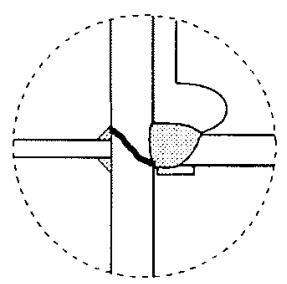

TYPE 5

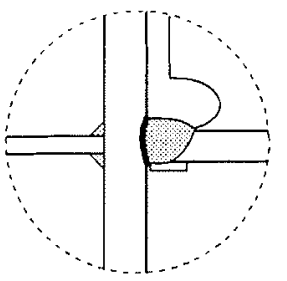

TYPE 2

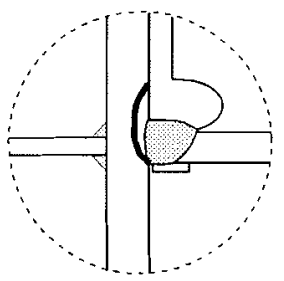

TYPE 4

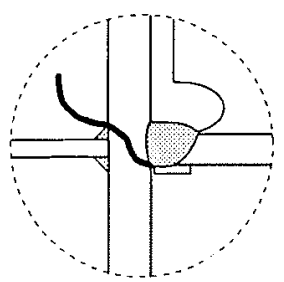

TYPE 6
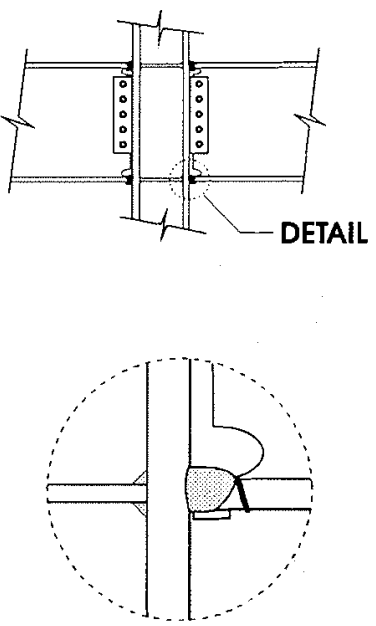

TYPE 7

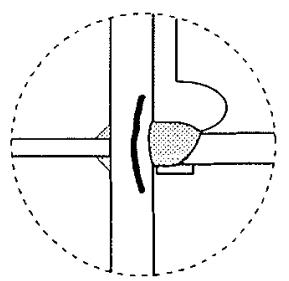

TYPE 8 and, as mentioned earlier, the full-penetration welded flange connection was still recommended in U.S. codes and extensively used in California at the time of the earthquake. Thus, the considerable number of brittle failures that occurred in the Northridge area as a result of the earthquake was not surprising. However, the reasons for the failures observed in laboratory had not yet been clearly identified by researchers. Thus, only tentative explanations could be formulated for the damage experienced by steel moment resisting frames in the Northridge earthquake.

Cracking of the beam flange welds has been mainly attributed to overstressing of the welds and to weld defects. During the welding process, significant stresses can be induced in the welds because moment connections are highly restrained. Upon loading, welds become overstressed because of the inadequacy of the bolted web connection to transfer bending moments; at the column face, increased axial stresses develop in the beam flanges as the full plastic moment of the beam must be entirely resisted by the flanges only. The fact that actual beam material may exhibit lower tensile to yield strength ratios could also have contributed in overloading the welds of the beam flanges.

These high stresses make the connections sensitive to weld imperfections. After the earthquake, weld flaws of many types have been identified on failed connections: lack of fusion and penetration in the root region of the welds, inadequate fusion between multipath welds and adjacent base metal, use of "end dams" instead of proper weld tabs, slag inclusions left in the welds because of the nature of the access to the area to be welded, etc. Inadequate preheat and cooling rates are also seen as possible contributors to weld failures. In addition, left-in-place steel backing bars create a notchlike condition (Fig. 43) that may have led to stress concentration in the welds and initiation of cracking.

The presence of beam flange continuity plates between the flanges of the columns may also have played a role in the weld failures. For instance, two 18-storey buildings displayed beam-column joint fractures; however, one structures' extent of weld failure was more than the others. The main difference in construction between the two high-rises was the use of continuity plates in columns. The building with the beam flange continuity plates had less weld failures than its counterpart, which suggests that the flexibility of the column flanges could have resulted in local overstressing of the welds.

The predominance of failures at the beam bottom flange, rather than at the top flange, has been partly attributed to the additional rotational restraint introduced by the composite floor slab and the web connector, the latter being usually located close to the top flange. Bottom flange welds are also seen as better candidates for premature fracture. Weld execution at the bottom flange is more difficult because of the beam web interference, which makes these welds more prone to imperfections. Another possible reason why weld failures occurred at the bottom flange is the fact that the notchlike condition at the top flange exists on the side of the flange opposite to the side subjected to the maximum beam flexural stresses, which is less critical than the situation prevailing at the bottom flange.

Other contributing factors to the observed weld failures 
have been suggested: inadequate field inspection, deficient through-thickness strength of column flanges, insufficient toughness of the material, high loading rates and strain rate effects, large size of the connecting members, actual state of stress in the welds and connected parts, etc. It is also believed that tensile axial loads developed in columns during the ground shaking, which would have been propitious to crack propagation into the column flanges and webs.

Though an alarmed reaction is not warranted at this time, since it is significant that none of the reported connection failures led to collapse, the causes of such a deficiency must promptly be identified and the current state-of-practice modified accordingly to ensure that building structures can survive much longer duration earthquakes, as expected to occur in some areas of the country. This revision process will undoubtedly affect the steel industry in Canada where this type of connection is common in practice (CISC 1991). Also of consequence is the fact that existing structures will also need to be included in this review program.

Steel frames damaged in the Northridge area will obviously represent a potential hazard in future earthquakes and must therefore be inspected and repaired. Thus, shortly after the earthquake, the California Seismic Safety Commission issued a public notice stating that steel buildings were potentially damaged and should be investigated. The City of Los Angeles also issued a draft regulation which required all owners of steel buildings to have their structures examined by a structural engineer. Even moment resisting frames that are found undamaged after the earthquake may need to be retrofitted to withstand properly next earthquakes. It must be realized, however, that the potential problem of existing moment resisting frames, either damaged or undamaged, is not limited to the Northridge region. Any steel moment frame that has sustained ground shaking in the past may have suffered some structural damage and can be vulnerable to future earthquakes. Similarly, undamaged existing moment resisting frames built in seismic regions may pose serious risks in future seismic events.

In March 1994, a special task committee of the American Iron Steel Construction (AISC) proposed interim recommendations for the repair of damaged connections and the design of new moment resisting frames (AISC 1994a). For repair, it was suggested that any cracked material or weld be removed and replaced by new steel material or welding. Of course, fabrication and welding practices were to strictly meet applicable code requirements. In addition, based on the current state of knowledge at that time, three options were proposed to enhance the performance of the joint. These are illustrated in Fig. 45 for the connection shown in Fig. 43.

Firstly, it was suggested that the backing bars of the beam flange welds be removed, the weld root region backgouged and rewelded, and, subsequently, a reinforcing fillet weld be applied. Second, the beam web was to be welded directly to the column or, alternatively, to the vertical shear connectors as shown in Fig. 45. The third correction consisted in adding flange reinforcement plates, either vertical ribs or cover plates, to help transferring to the column the axial loads acting in the beam flanges. The decision of using only one or more of those three schemes was left to the engineer. Examples of these repair procedures are presented by Sabol (1994) and by Tide (1994). For the design of new structures, AISC recommended to implement these repair provisions when
Fig. 45. Proposed reinforced beam-column joints for retrofit and new constructions: $(a)$ vertical ribs; $(b)$ cover plates (adapted from Engelhardt and Sabol 1994).
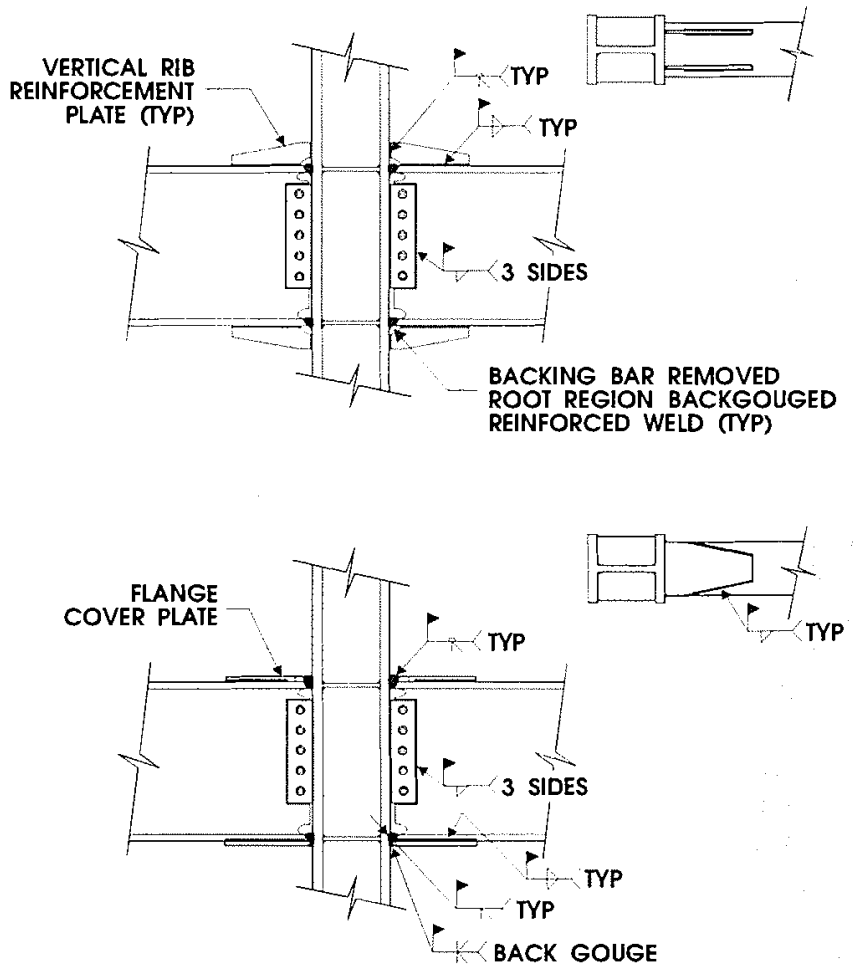

making use of the standard welded flange and bolted web connection specified in the 1992 AISC Seismic Provisions for Structural Steel Buildings.

Meanwhile, research has been initiated in the United States, as well as in other countries, to explain the observed connection failures and to propose solutions. In particular, a test program was started in April 1994 to develop guidelines for improved moment connections (Engelhardt and Sabol 1994). A total of 16 full-scale specimens made of heavy members were tested under cyclic loading, which permitted to examine the performance of four different connection details. Testing was completed in October 1994. Based on the results and additional knowledge gained during that period of time, AISC published a second set of interim guidelines for repair and design of steel moment resisting frames (AISC 1994b). These test results and guidelines are briefly summarized in the following.

The first connection detail was of the standard welded flange and bolted type (Fig. 43), but the beam flange welds had been improved as shown in Fig. 45a. The second connection was similar except that the beam web was welded directly to the column, making this connection an all-welded detail. Upon loading, all specimens of these two connection details experienced brittle fracture at the beam flange weld early in the test, with no or little plastic rotation in the beam.

The third type of joint included reinforcement plates as illustrated in Fig. 45. Cover plates were used in eight samples whereas two specimens included vertical ribs. More effort was directed toward the testing of cover-plated specimens as this detail appears to be less expensive. In these samples, the section modulus at the face of the column ranged between 1.6 and 2.0 times that of the unreinforced beam. 
Standard bolted web connection was used in these connections. In all samples but two, the beam underwent large plastic rotation (between 0.025 and $0.035 \mathrm{rad}$ ) and exhibited high energy dissipation. Both failures initiated in beam flange weld of cover-plated connections. In one sample, failure took place at the interface of the weld and the column flange, whereas crack propagated into the column flange material in the second failed specimen.

The fourth connection design examined in the test program included side straps connecting the outer edges of the beam flanges to the outer edge of the column continuity plates. This arrangement (not shown here) had been proposed to avoid through-thickness failure of the column flange. In the tests, both samples of this joint exhibited only fair performance with failure occurring at plastic rotations less than $0.02 \mathrm{rad}$ (this value is generally considered as the minimum level for acceptance). This detail was also the most costly to fabricate.

Although limited in scope, this experiment clearly indicated that improving welding quality was not sufficient by itself to achieve the desired performance. On the other hand, shifting the plastic hinging in the beams away from the face of the column by reducing the stress level in the welds through reinforcement plates appeared to be promising. However, brittle failures still occurred in the reinforced connections, which suggests that other issues such as the throughthickness properties of the column flange material and the presence of continuity plates (one of the reinforced joint which failed early did not have continuity plates) need further investigation.

On the basis of these findings, AISC reiterated that the use of the standard welded beam and bolted web connection described in the 1992 Seismic Provisions should be suspended unless it can be shown that such connection is adequate or that proper reinforcement is provided. It must be noted that in September 1994, the ICBO had deleted from the 1994 UBC code the section that allowed the use of this connection without testing and calculation. In view of the difficulty experienced in achieving high quality welds and detecting weld defects in the test program, AISC also recommended that all welding be performed in strict compliance with comprehensive welding procedure specifications to be developed for each project and suggested that ultrasonic testing of groove welds be conducted from the top and bottom sides of the welds as well as from the back side of the column flange.

American Institute of Steel Construction also developed tentative provisions to assess the adequacy of existing connections and to design reinforced joints (Englekirk 1994). The approach directly accounts for material overstrength, lower reliability of through-thickness resistance of steel, and actual stress - strain relationships of the different materials involved (weld, base metal, etc.). It also includes ultimate strain limit states for weld metal and steel material. Unfortunately, the testing program did not investigate all the possible contributing factors to the observed connection failures in Northridge and the provisions could not be thoroughly validated. Moreover, data on the mechanical properties of the material and on the initial state of stress and strain in connections are also insufficient. Even the expected demand on the components of moment resisting frames in future earth- quakes, including the effects of vertical accelerations, needs to be established for design purposes.

Thus, not enough information is yet available to structural engineers for implementing sound repair schemes or designing reinforced connections in moment resisting frames. The Structural Engineers Association of California (SEAOC), the Applied Technology Council (ATC), and the California Universities for Research in Earthquake Engineering (CUREE) have engaged in a joint effort, namely the SAC Joint Venture, to solve this problem. Their objectives are to understand what happened to steel moment resisting frames in the Northridge earthquake, to provide guidance for the identification and assessment of damage in buildings, and, finally, to prepare recommendations for the repair, retrofit, and design of steel moment resisting frames.

The initial phase of this research effort started in November 1994 and is mainly devoted to the development of interim guidelines for the repair and inspection of existing structures. This $\$ 2.3$ million U.S. program, which is funded by the Federal Emergency Management Agency and the California Office of Emergency Services, is expected to be completed in the Spring of 1995 (A. Ross, 1994, private communication). Within the next 3 years, it is expected that an additional $\$ 10$ million U.S. research will be carried out by the SAC Joint Venture to reach its objectives. Findings of this research and other research programs that are conducted elsewhere would need to be examined for possible inclusion in Canadian codes.

Other avenues which have been proposed to enhance the seismic performance of steel moment frames should also draw the attention of researchers and designers in the coming years. For example, intentionally weakening the beams at a certain distance of the columns would force plastic hinging in beams away from the connections as reinforcement plates do. This can be easily achieved by reducing the width of the flanges over a certain length to create a dog-bone shape, as proposed by Chen and Yeh (1994), or by drilling holes in the beam flanges. Similar behavior could also be obtained by adding haunches to moment connections. As opposed to other joints, such a reinforcement scheme would exhibit higher redundancy in the connection, since failure of a single weld would not lead to nearly losing all the bending strength and stiffness of the connection (Bertero et al. 1994). Endplate beam-column moment connections, when properly sized, can also be seen as a viable alternative for ductile response under seismic loading (Tsai and Popov 1990).

Of course, means of dissipating energy other than beam hinging can also be exploited. Shear yielding in the column joint panel zone has been known as an efficient way of releasing the inelastic demand on beams and beam-to-column connections (Popov et al. 1988). The implementation of dissipating energy devices and base isolation systems in moment resisting frames also represents a promising avenue, both for retrofit projects and new structures.

Connections failures in moment resisting frames also raised serious concerns on the overall reliability of structures braced only by a few moment resisting bays. These structures can be very sensitive to failure of a single connection and it is questionable whether such a nonredundant system should classify under the ductile moment resisting frame category for which superior redundancy is implied. This 
issue should be addressed in future editions of building codes in Canada.

\section{Conclusions}

Some concentrically steel braced frames and steel moment resisting frames experienced various structural and nonstructural damage during the Northridge earthquake. None of them collapsed as they generally maintained their gravity load carrying capacity as well as some degree of lateral stability.

The observations made and the information presented in this paper support for the most part the relevance of the current seismic design provisions included in the Canadian building code and standard for steel structures. However, Canadian researchers, code writing committees, and structural engineer designers will need to address a number of additional issues which can have a significant impact on the seismic resistant design of steel structures and which are not (or deficiently) addressed by the current edition of the Canadian codes and standards. This includes the need to

- extend a capacity design approach to the whole lateral load resisting system of the structure, as well as to all categories of moment resisting frames and, particularly, concentrically braced frames, because of their lower inherent redundancy;

- account for secondary effects that occur upon buckling of bracing members in concentrically braced frames;

- consider vertical ground accelerations in the design of horizontal cantilever structures and exterior columns of bracing bents in concentrically braced frames;

- account for the lower redundancy exhibited by moment resisting frames having only a few moment resisting bays;

- recognize in the design process the hazard potential from nonstructural damage occurring during earthquakes.

The first item is most important as the benefits of capacity design in ensuring a stable ductile behavior positively impact structural performance, particularly in view of the large uncertainties involved in the definition of the design earthquake.

One of the main lessons learned from the Northridge earthquake is the potential deficiency of welded flange and bolted web beam-column joints in moment resisting frames. The observation of the damage and the research performed so far indicate that this type of connection is not adequate to allow cyclic flexural hinging to take place in beams. Though some interim guidelines have been proposed for the repair, retrofit, and design of beam-column joints in moment resisting frames, further research is still needed to determine the causes of this deficiency and to propose sound connection details and design rules. The findings of this work may eventually justify the need for strengthening existing moment resisting frames in seismically active regions of Canada, even those designed under recent code provisions.

Finally, the Northridge earthquake has sent a strong signal that careful inspection of steel frames is mandatory after a seismic event, even though only minor damage is apparent from visual preliminary examination.

\section{Acknowledgements}

The authors gratefully acknowledge the Natural Sciences and Engineering Research Council of Canada for providing research funds for the reconnaissance visits and subsequent investigations. The on-site cooperation of Susan K. Tubbesing of the Earthquake Engineering Resarch Institute, John Hall of Caltech, and Bob Harder, Manager of the Van Nuys Office of the Los Angeles Buildings and Safety Division, is greatly appreciated. The assistance of John Sherstobitoff of Sandwell Inc., Denis Mitchell of the Department of Civil Engineering of McGill University, and René Tinawi of the Department of Civil Engineering of École polytechnique during the reconnaissance, together with conveyance of information and photographs from David Bonneville, Jay Love, and James O. Malley of H.J. Degenkolb Associates of San Francisco is gratefully acknowledged. Material extracted from conversations with local Los Angeles engineers Charles Thiel, Jock Scott, and Geoffrey Hichborn Sr. is similarly appreciated. Michael Engelhardt of the Department of Civil Engineering, University of Texas, Austin, and Arthur Ross of the Structural Engineers Association of California, California, are also sincerely thanked for their contribution to the paper. The information provided by CSIMP, OES, and USGS was invaluable in interpreting the ground motion characteristics.

\section{References}

AISC. 1992. Seismic provisions for structural steel buildings. American Institute of Steel Construction, Inc., Chicago, Ill.

AISC. 1994a. Executive summary - Interim observations and recommendations of AISC Special Task Committee on the Northridge Earthquake. Proceedings of AISC Special Task Committee on the Northridge Earthquake Meeting, American Institute of Steel Construction, Chicago, Ill.

AISC. 1994b. AISC Northridge Technical Bulletin No. 2 Interim observations and recommendations on steel moment resisting frames. Northridge Steel Update I, American Institute of Steel Construction, Chicago Ill.

Astaneh-Asl, A., Goel, S.C., and Hanson, R.D. 1985. Cyclic out-of-plane buckling of double angle bracing. ASCE Journal of Structural Engineering, 111: $1135-1153$.

Bertero, V.V., Anderson, J.C., and Krawinkler, H. 1994. Performance of steel building structures during the Northridge earthquake. Earthquake Engineering Research Center, College of Engineering, University of California, Berkeley, Calif., Report No. UCB/EERC-94/09.

Bonneville, D.R. 1994. Northridge earthquake damage to a modern steel braced frame office building. Proceedings of the AISC Special Task Committee on the Northridge Earthquake Meeting, Chicago, Ill.

Bruneau, M., and Mahin, S.A. 1990. Full-scale tests of butt-welded splices in heavy-rolled steel sections subjected to primary tensile stresses. Engineering Journal, American Institute of Steel Construction, 28: $1-17$.

BSSC. 1991. National Earthquake Hazards Reduction Program (NEHRP) recommended provisions for the development of seismic regulations for new buildings. Part I: provisions. Building Safety Seismic Council, Washington, D.C.

Chen, S.-J., and Yeh, C.H. 1994. Enhancement of 
ductility of steel beam-to-column connections for seismic resistance. Proceedings of the Structural Stability Research Council 1994 Task Group Meetings and Technical Session, Bethlehem, Pa., pp. 327-338. Cheng, R.J.J., Rabinovitch, J.S., and Yam, M.C.H. 1993. Behavior of gusset plate connections under compressive monotonic and cyclic loadings. Proceedings of the 1993 Annual Technical Session of the Structural Stability Research Council, Milwaukee, Wis.

CISC. 1991. Handbook of steel construction. 5th ed. Canadian Institute of Steel Construction, Willowdale, Ont.

CSA. 1989. Limit state design of steel structures. Canadian Standards Association, Rexdale, Ont., Standard CAN/CSA-S16.1-M89.

EERI. 1994. Northridge earthquake January 17, 1994 Preliminary reconnaissance report. Earthquake Engineering Research Institute, Oakland, Calif., Report No. 94-01.

Engelhardt, M.D., and Hussain, A.S. 1993. Cyclicloading performance of welded flange-bolted web connections. ASCE Journal of Structural Engineering, 119: $3537-3549$.

Engelhardt, M.D., and Sabol, T.A. 1994. Testing of welded steel moment connections in response to the Northridge earthquake. Progress report to the AISC Advisory Subcommittee on Special Moment Resisting Frames Research, Northridge Steel Update I, American Institute of Steel Construction, Chicago, Ill.

Englekirk, R.E. 1994. Design implications derived from the University of Texas, Austin, test program. Northridge Steel Update I, American Institute of Steel Construction, Chicago, Ill.

Filiatrault, A., Anderson, D.L., and DeVall, R.H. 1992. Effect of weak foundation on the seismic response of core wall type buildings. Canadian Journal of Civil Engineering, 19: 530-539.

Finn, W.D., and Ventura, C.E. 1994. Ground motions. Preliminary report on the Northridge, California, earthquake of January 17, 1994. Canadian Association for Earthquake Engineering, Vancouver, B.C., pp. 7-71.

Ghosh, S.K. 1994. Code implications of the Northridge earthquake of January 17, 1994. Proceedings of the Sixth ATC 15-5 U.S. - Japan Workshop on the Improvement of Building Structural Design and Construction Practices, Victoria, B.C., pp. 3.1-3.16.

ICBO. 1982. Uniform building code. International Conference of Building Officials, Whittier, Calif.

ICBO. 1994. Uniform building code. International Conference of Building Officials, Whittier, Calif.

Khatib, I.F., Mahin, S.A., and Pister, K.S. 1988. Seismic behavior of concentrically braced steel frames. Earthquake Engineering Research Center, University of California, Berkeley, Calif., Report No. UCB/EERC-88/01.

Knoll, F. 1993. Seismic performance of reinforced concrete ductile moment-resisting frame buildings located in different seismic regions: Discussion. Canadian Journal of Civil Engineering, 20: 333. Liu, Z., and Goel, S.C. 1988. Cyclic load behavior of concrete-filled tubular braces. ASCE Journal of Structural Engineering, 14: 1488-1506.

Miller, D.K. 1994. Northridge: the role of welding clarified. The Welding Innovation Quarterly, The James F. Lincoln Arc Welding Foundation, IX: 4-13.

Mitchell, D., DeVall, R.H., Saatcioglu, M., Simpson, R., Tinawi, R., and Tremblay, R. 1995. Damage to concrete structures due to the 1994 Northridge earthquake. Canadian Journal of Civil Engineering, 22: 361-377.

NRCC. 1990. National building code of Canada, 1990. 10th ed. Associate Committee on the National Building Code, National Research Council of Canada, Ottawa, Ont.

Popov, E.P., and Black, R.G. 1981. Steel struts under severe cyclic loadings. ASCE Journal of the Structural Engineering Division, 107: 1857-1881.

Popov, E.P., Tsai, K.-C., and Engelhardt, M.D. 1988. On seismic steel joints and connections. Proceedings of the 57th Annual Convention, Structural Engineers Association of California, Makahiki, Hawaii, pp. $187-208$.

Priestley, M.J.N. 1993. Myths and fallacies in earthquake engineering - conflicts between design and reality. Bulletin of the New Zealand National Society for Earthquake Engineering, 26: 329-348.

Redwood, R.G., and Channagiri, V.S. 1991. Earthquake resistant design of concentrically braced steel frames. Canadian Journal of Civil Engineering, 18: 839-850.

Redwood, R.G., Lefki, L., and Amar, G. 1990. Earthquake resistant design of steel moment resistant frames. Canadian Journal of Civil Engineering, 17: $659-667$.

Roeder, G.C., Carpenter, J.E., and Taniguchi, H. 1989. Predicted ductility demands for steel moment resisting frames. Earthquake Spectra, 5: 409--427.

Ross, A.E., and Mahin, S.H. 1994. Steel moment resisting frames and the Northridge earthquake. Proceedings of the Sixth ATC 15-5 U.S. - Japan Workshop on the Improvement of Building Structural Design and Construction Practices, Victoria, B.C., pp. 10.1-10.10.

Sabol, T.A. 1994. Damage to ductile steel frames in the Northridge earthquake. Proceedings of AISC Special Task Committee on the Northridge Earthquake Meeting, Chicago, Ill.

Tide, R.H.R. 1994. Fracture of welded beam-to-column connections when subjected to seismic loadings. Proceedings of AISC Special Task Committee on the Northridge Earthquake Meeting, Chicago, Ill.

Tremblay, R., and Stiemer, S.F. 1993. A contribution to friction bolted connections for concentrically braced steel frames. Is your structure suitably braced? 1993 Structural Stability Research Council Conference, Milwaukee, Wis., pp. 189-200.

Tsai, K.-C., and Popov, E.P. 1990. Cyclic behavior of end-plate moment connections. ASCE Journal of Structural Engineering, 116: 2917-2930.

White, R.N., and Salmon, C.G. 1987. Building structural design handbook. John Wiley \& Sons, New York, N.Y.

Yanvec, P.I., Gillengerten, J.D., and Hamburger, R.O. 1991. The performance of steel buildings in past earthquakes. American Iron and Steel Institute and EQE Engineering, Inc., Washington, D.C. 